\title{
Aerosol decadal trends - Part 2: In-situ aerosol particle number concentrations at GAW and ACTRIS stations
}

\author{
A. Asmi ${ }^{1,16}$, M. Collaud Coen ${ }^{2}$, J. A. Ogren ${ }^{3}$, E. Andrews ${ }^{3,4}$, P. Sheridan ${ }^{3}$, A. Jefferson ${ }^{3,4}$, E. Weingartner ${ }^{5}$, \\ U. Baltensperger ${ }^{5}$, N. Bukowiecki ${ }^{5}$, H. Lihavainen ${ }^{6}$, N. Kivekäs ${ }^{6}$, E. Asmi ${ }^{6}$, P. P. Aalto ${ }^{1}$, M. Kulmala ${ }^{1}$, \\ A. Wiedensohler ${ }^{7}$, W. Birmili ${ }^{7}$, A. Hamed ${ }^{7,8}$, C. O'Dowd ${ }^{9}$, S. G Jennings ${ }^{9}$, R. Weller ${ }^{10}$, H. Flentje ${ }^{11}$, A. M. Fjaeraa ${ }^{12}$, \\ M. Fiebig ${ }^{12}$, C. L. Myhre ${ }^{12}$, A. G. Hallar ${ }^{13}$, E. Swietlicki ${ }^{14}$, A. Kristensson ${ }^{14}$, and P. Laj ${ }^{15}$ \\ ${ }^{1}$ Department of Physics, University of Helsinki, P.O. Box 64, 00014, Finland \\ ${ }^{2}$ Federal Office of Meteorology and Climatology, MeteoSwiss, 1530 Payerne, Switzerland \\ ${ }^{3}$ NOAA Earth System Research Laboratory, Boulder, USA \\ ${ }^{4}$ Cooperative Institute for Research in Environmental Science, University of Colorado, Boulder, USA \\ ${ }^{5}$ Paul Scherrer Institute, Laboratory of Atmospheric Chemistry, 5232 Villigen, Switzerland \\ ${ }^{6}$ Finnish Meteorological Institute, Erik Palmenin aukio 1, 00560 Helsinki, Finland \\ ${ }^{7}$ Leibniz Institute for Tropospheric Research, Permoserstrasse 15, 04318 Leipzig, Germany \\ ${ }^{8}$ Department of Applied Physics, University of Eastern Finland, Kuopio, Finland \\ ${ }^{9}$ School of Physics and Centre for Climate \& Air Pollution Studies, Ryan Institute, National University of Ireland Galway, \\ University Road, Galway, Ireland \\ ${ }^{10}$ Alfred Wegener Institute for Polar and Marine Research, Am Handelshafen 12, 27570 Bremerhaven, Germany \\ ${ }^{11}$ Deutscher Wetterdienst, Meteorological Observatory Hohenpeissenberg, Albin-Schwaiger-Weg 10, \\ 82383 Hohenpeissenberg, Germany \\ ${ }^{12}$ NILU - Norwegian Institute for Air Research, Instituttveien 18, 2027 Kjeller, Norway \\ ${ }^{13}$ Desert Research Institute, Storm Peak Laboratory Division of Atmospheric Sciences, Steamboat Springs,USA \\ ${ }^{14}$ Division of Nuclear Physics, Lund University, P.O. Box 118, 22100 Lund, Sweden \\ ${ }^{15}$ UJF-Grenoble 1/CNRS, LGGE, UMR5183, Grenoble, 38041, France \\ ${ }^{16}$ Laboratoire de Météorologie Physique, CNRS-Université Blaise Pascal, UMR6016, Clermont Ferrand, France
}

Correspondence to: A. Asmi (ari.asmi@helsinki.fi)

Received: 25 July 2012 - Published in Atmos. Chem. Phys. Discuss.: 20 August 2012 Revised: 7 December 2012 - Accepted: 2 January 2013 - Published: 22 January 2013

\begin{abstract}
We have analysed the trends of total aerosol particle number concentrations $(N)$ measured at long-term measurement stations involved either in the Global Atmosphere Watch (GAW) and/or EU infrastructure project ACTRIS. The sites are located in Europe, North America, Antarctica, and on Pacific Ocean islands. The majority of the sites showed clear decreasing trends both in the full-length time series, and in the intra-site comparison period of 2001-2010, especially during the winter months. Several potential driving processes for the observed trends were studied, and even though there are some similarities between $N$ trends and air temperature changes, the most likely cause of many northern hemisphere trends was found to be decreases in the an-
\end{abstract}

thropogenic emissions of primary particles, $\mathrm{SO}_{2}$ or some coemitted species. We could not find a consistent agreement between the trends of $N$ and particle optical properties in the few stations with long time series of all of these properties. The trends of $N$ and the proxies for cloud condensation nuclei $(\mathrm{CCN})$ were generally consistent in the few European stations where the measurements were available. This work provides a useful comparison analysis for modelling studies of trends in aerosol number concentrations. 


\section{Introduction}

Aerosol particles have a wide range of effects on health, visibility, and climate. In general, higher aerosol concentrations are usually associated with increased health risks (e.g. Dockery and Pope, 1994; Donaldson et al., 1998; WHO Working Group, 2003), decreased visibility (e.g. Charlson, 1969; Schichtel et al., 2005; Pitchford et al., 2005), and, for nonabsorbing particles, cooling of the atmosphere (e.g. IPCC, 2007), although all of these effects are very much dependent on aerosol size distribution and composition. Notably, the number concentration of potential cloud condensation nuclei (CCN) particles is a key parameter controlling the aerosolcloud interaction, and changes in the global CCN concentrations could affect the climate system significantly (Lohmann and Feichter, 2005).

This is the second part of the aerosol trends analysis initiative, with the companion paper concentrating on the trends of aerosol optical properties (Collaud Coen et al., 2013). In this paper, we provide information on the particle number concentration and (on more limited scale) particle number size distribution trends, compare the results of the two papers, and explore some potential drivers of the observed trends. Due to this two-paper format, we refer to the companion paper for more in depth literature review of aerosol climate, air quality, and visibility impacts, and on the past explorations of aerosol trends.

One key aspect of aerosol populations is the number concentration of aerosol particles. Number concentrations were one of the first quantitative measures of aerosol concentrations in ambient air (Aitken, 1889), and subsequent developments in instrumentation (McMurry, 2000) have made them a semi-standard measurement at many long-term air observatories (Global Atmosphere Watch, 2003). Aerosol number concentrations $(N$, or condensation nuclei, $\mathrm{CN})$ measured with condensation nuclei counters are a bulk property of the aerosol number size distribution, and thus integrate over a wide range of aerosol properties and sensitivities to different processes. Particle lifetimes are highly variable: both the smallest (less than around $50 \mathrm{~nm}$ in diameter) and largest end $\left(\mathrm{d}_{p}>1000 \mathrm{~nm}\right)$ of the aerosol number size distributions have much lower lifetimes in the atmosphere than the main part of the distribution, concentrated around the Aitken and accumulation modes (Jaenicke, 2008). The aerosol number concentration variability thus has contributions from relatively short time-scale processes of small and large particles, and relatively long time-scale processes dominating the Aitken and accumulation modes. This is one of the reasons why size selective number concentration measurements are of particular use for aerosol-climate trend analysis. Unfortunately, long datasets of such measurements are scarce (four stations in this analysis), and concentrated in Europe. Although recently significant improvements in the site density for such measurements have been done globally in the con- text of the GAW network or the ACTRIS EU-Infrastructure project, they will only benefit future studies.

Particles across the whole particle size spectrum are not equally relevant to climate. Numerous and highly variable nano-particles with diameters less than approximately $50 \mathrm{~nm}$ do not act as CCN before they grow to larger sizes, (e.g. McFiggans et al., 2006) although they can make up the bulk of the aerosol number population. In contrast, long-lived accumulation mode particles (usually between $100 \mathrm{~nm}$ and $1 \mu \mathrm{m}$ diameter) are generally good $\mathrm{CCN}$, can scatter light efficiently, and, especially in polluted areas, often contain black or brown carbon. Thus climate impacts of aerosols are not, even in clean areas, necessarily proportional to total particle number concentration. Particle growth processes (especially condensation and cloud processing) are important in moving the small nanoparticles to particle sizes with long lifetime and more climate relevance (Pierce and Adams, 2007). Condensational growth does not directly affect the particle number concentration total, but should, in the end, increase the long-term number concentration average, as the particles live longer in the atmosphere.

New particle formation creates particles at the smallest end of the aerosol number size spectrum, which has the tendency of increasing number concentration variability and the mean number concentration, but, until the particles grow significantly, will not have a strong effect on climate (Kerminen et al., 2012). Most nucleation events happen during daytime (Kulmala et al., 2004b), in contrast to seemingly more localized and rare night-time nucleation (e.g. Ortega et al., 2012), and the initial growth to more $\mathrm{CCN}$-relevant particle sizes usually happens in continental atmospheres within the same day or the next night (Sihto et al., 2011). Modelling studies indicate that on a global scale the fraction of particles originating from new particle formation accounts for a large fraction of the total particle number concentration (Spracklen et al., 2006, 2010; Makkonen et al., 2009). Mechanisms involved in the formation of secondary aerosols are complex and influenced by gaseous precursors, concentrations of existing aerosol, and atmospheric conditions (e.g. RH, $T$, radiation, presence of clouds). A recent modelling study of the aerosol particle number concentration trends evaluated the possibility that increasing air temperatures might decrease particle nucleation rates and thus global $N$ concentrations (Yu et al., 2012).

The long-term variability of aerosol particle number concentration is relevant for climate research, as it can reveal important feedback mechanisms that need to be accounted for in projection studies, provide important information on past drivers of climate change, and give a useful comparison parameter for long-term simulations of atmospheric chemistry. Analyses of the variability of aerosol number concentration and size have been performed by many studies, in particular from regionally representative stations of the Global Atmosphere Watch (GAW) network or affiliated to the EU-Infrastructure ACTRIS. Measurements are reported 
for stations located within the planetary boundary layer at rural and remote sites (e.g. Mäkelä et al., 2000; Birmili et al., 2003; Tunved et al., 2003; Rodríguez et al., 2005), in the Arctic atmosphere (Komppula et al., 2003), in marine environment (e.g. Yoon et al., 2007), and in the free troposphere (Nyeki et al., 1999; Weingartner et al., 1999; Venzac et al., 2009; Boulon et al., 2010; Hallar et al., 2011). Bodhaine (1983) reported measurements at the NOAA baseline stations. In general, aerosol number concentrations and size distributions at remote continental sites show high seasonality, suggesting that biogenic processes can significantly affect the number concentrations in these regions and that photochemical processes can also affect this variability. The high seasonality can easily mask any other long-term variability, if not properly taken into account. At other locations, such as Central European sites, the aerosol background does not show such high seasonal variability and appears to be controlled more directly by the emission intensity (Asmi et al., 2011). As noted in the companion paper, aerosol number concentration trends have not been so widely studied as trends in other aerosol properties, especially particulate matter mass concentrations (PM) and aerosol optical depth (AOD).

It is necessary to have access to time series over sufficient duration to distinguish between short-term variability and long-term trends. Continuous measurements of aerosol number concentration and size were initiated in the mid-70's at some stations (South Pole, Barrow, American Samoa and Mauna Loa) as part of the NOAA network (Bodhaine, 1983), but it is only from the early 90's that reporting aerosol number concentrations or number size distributions have become more common. As of today, nearly 30 stations are regularly reporting number concentration information, many including the number size distribution information, to the World Data Center for Aerosols (WDCA) but very few records span over more than 5 yr. As discussed in Collaud Coen et al. (2013), analyses of long-term trends for aerosol physical properties require at least $10 \mathrm{yr}$ long records, which explains why very few studies have been published on aerosol particle number concentration trends.

Our aim is to provide reliable information on aerosol number concentration decadal trends. We study the similarities to aerosol optical properties trends (using results from the companion paper) and discuss potential causes for the long-term trends. We also evaluate the trends of aerosol number size distributions in locations where such information is available, and study the applicability of aerosol particle number concentration trends to $\mathrm{CCN}$-sized aerosol properties in these environments. The results are meant to be consistent and robust for end-user groups from aerosol specialists to climate modellers.

\section{Theory and methods}

\subsection{Measurement sites}

Table 1 summarizes the sites and the instrumentation used in this analysis. Most of the sites used in this study are in the Global Atmosphere Watch (GAW) program, with associated quality control and measurement standards (Global Atmosphere Watch, 2003). Some additional European sites, with long time series of size distribution data used standard operating procedures that have been implemented within the European infrastructure EUSAAR and ACTRIS or within the GUAN network in Germany (Philippin et al., 2009; Birmili et al., 2009; Wiedensohler et al., 2012). Notably, all stations in this study are located at regional background locations, which in this context means that the stations are not near (within a few kilometres) obvious strong anthropogenic sources, such as cities, factories or highways. This is not to say that there is no anthropogenic influence: even Antarctic stations have the potential of pollution from the station itself. The sites are described in detail in Table 1. Additional site information is found in the companion paper (Collaud Coen et al., 2013), in Asmi et al. (2011) for Hyytiälä, Pallas, Melpitz and Vavihill, Laakso et al. (2003) for Värriö, Borys and Wetzel (1997) for Storm Peak Laboratory, and Bodhaine (1983) for American Samoa.

\subsection{Instrumentation}

The aerosol particle number concentrations were measured with a variety of condensation particle counters (condensation nuclei counters), which differed significantly in type and performance from site-to-site (Table 1). The sites generally operated similar or often the very same instrument through the analysis period, and if the instrumentation change was considered major, the data were either split into two parts (stations SPO and SMO) or a part of the time series was not included in the analysis (e.g. station MHD measurements in 1990's). The main criterion for having a dataset of one station was at least $10 \mathrm{yr}$ of relatively continuous measurements. Longer gaps are mentioned in Table 2, and can affect the trend results.

The number size distribution measurements were obtained by custom-made mobility particle size spectrometers (differential mobility particle sizer, DMPS) systems, which stayed relatively unchanged during the whole measurement period. In Hyytiälä, the DMPS inversion routine has changed during the period, but the measurements were considered to be comparable by the data providers. All of the stations included in the size distribution analyses had either constant monitoring of the instrument by measurement personnel (Hyytiälä) or effective site calibration routines. 
Table 1. Measurement sites and instrumentation used in the trend analysis. The lower detection limit in particle diameter (LDL) is indicated as a nominal value from the instrument manufacturer (Liu and Kim (1977) for GE CNC NO7006), and the particle range used for the size distribution measurements. The start times of each measurement are given in ISO 8601 format (YYYY-MM-DD). Last column lists the dataset acronym.

\begin{tabular}{|c|c|c|c|c|c|c|c|}
\hline Site & Area & Coordinates & Elev.(m) & Instrument & $\mathrm{LDL}(\mathrm{nm})$ & Start time & $\begin{array}{r}\text { Dataset } \\
\text { Acronym }\end{array}$ \\
\hline Neumayer & ANT & $70.67^{\circ} \mathrm{S} 8.27^{\circ} \mathrm{W}$ & 42 & TSI 3022 & 7 & $1995-11-31$ & NMY \\
\hline \multirow[t]{2}{*}{ South Pole } & ANT & $90.00^{\circ} \mathrm{S} 24.80^{\circ} \mathrm{W}$ & 2841 & GE CNC NO7006 & 9 & 1974-01-01 & SPO1 \\
\hline & & & & TSI 3760 & 15 & 1989-01-01 & $\mathrm{SPO} 2$ \\
\hline Hohenpeissenberg & EUR & $47.80^{\circ} \mathrm{N} 11.01^{\circ} \mathrm{E}$ & 985 & TSI 7610 & 15 & 1995-06-01 & HPB \\
\hline \multirow{2}{*}{ Jungfraujoch } & EUR & $46.55^{\circ} \mathrm{N} 7.99^{\circ} \mathrm{E}$ & 3580 & TSI 3010 & 10 & 1997-03-13 & JFJ \\
\hline & & & & TSI $3772^{\mathrm{a}}$ & 10 & 2009-02-13 & \\
\hline Mace Head & EUR & $53.33^{\circ} \mathrm{N} 9.89^{\circ} \mathrm{W}$ & 5 & TSI 3025 & 3 & 2000-01-01 & MHD \\
\hline Pallas & EUR & $67.97^{\circ} \mathrm{N} 24.12^{\circ} \mathrm{E}$ & 560 & TSI 3010 & 10 & 1996-01-01 & PAL \\
\hline Bondville & $\mathrm{NCA}$ & $40.05^{\circ} \mathrm{N} 88.37^{\circ} \mathrm{W}$ & 213 & TSI 3760 & 15 & 1994-06-20 & BND \\
\hline Barrow & $\mathrm{NCA}$ & $71.32^{\circ} \mathrm{N} 156.61^{\circ} \mathrm{W}$ & 11 & TSI 3760 & 15 & 1995-06-01 & BRW \\
\hline Southern Great Plains & NCA & $36.60^{\circ} \mathrm{N} 97.50^{\circ} \mathrm{W}$ & 318 & TSI 3010 & 10 & 1994-01-01 & SGP \\
\hline Storm Peak Laboratory ${ }^{b}$ & $\mathrm{NCA}$ & $45.460^{\circ} \mathrm{N} 106.74^{\circ} \mathrm{W}$ & 3220 & TSI 3010 & 10 & 1998-02-11 & SPL \\
\hline Mauna Loa & SWP & $19.54^{\circ} \mathrm{N} 155.58^{\circ} \mathrm{W}$ & 3397 & TSI 3760 & 15 & 1999-06-01 & MLO \\
\hline \multirow[t]{3}{*}{ Samoa } & SWP & $14.25^{\circ} \mathrm{S} 170.56^{\circ} \mathrm{W}$ & 77 & GE CNC NO7006 & 9 & 1973-06-01 & SMO1 \\
\hline & & & & TSI 3760 & 15 & 1992-05-01 & $\mathrm{SMO} 2$ \\
\hline & & & & TSI 3010 & 10 & $2004-02-21$ & \\
\hline \multicolumn{8}{|l|}{ Size distribution datasets } \\
\hline \multirow[t]{2}{*}{ Hyytiälä } & EUR & $61.85^{\circ} \mathrm{N} 24.29^{\circ} \mathrm{E}$ & 179 & DMPS & $20-500$ & 1996-01-19 & HYY20 \\
\hline & & & & DMPS & $100-500$ & & HYY100 \\
\hline \multirow[t]{2}{*}{ Pallas } & EUR & $67.97^{\circ} \mathrm{N} 24.12^{\circ} \mathrm{E}$ & 560 & DMPS & $20-500$ & 2000-04-11 & PAL20 \\
\hline & & & & DMPS & $100-500$ & & PAL100 \\
\hline \multirow[t]{2}{*}{ Melpitz } & EUR & $51.54^{\circ} \mathrm{N} 12.93^{\circ} \mathrm{E}$ & 87 & DMPS & $20-500$ & 1996-03-26 & MPZ20 \\
\hline & & & & DMPS & $100-500$ & & MPZ100 \\
\hline \multirow[t]{2}{*}{ Värriö } & EUR & $67.76^{\circ} \mathrm{N} 29.61^{\circ} \mathrm{E}$ & 390 & DMPS & $20-500$ & $1997-12-08$ & VAR20 \\
\hline & & & & DMPS & $100-500$ & & VAR 100 \\
\hline \multirow[t]{2}{*}{ Vavihill } & EUR & $56.01^{\circ} \mathrm{N} 13.09^{\circ} \mathrm{E}$ & 172 & DMPS & $20-500$ & $2001-11-23$ & VHL20 \\
\hline & & & & DMPS & $100-500$ & & VHL100 \\
\hline
\end{tabular}

ANT = Antarctica, EUR = Europe, NCA = North America and Caribbean, SWP = South West Pacific,

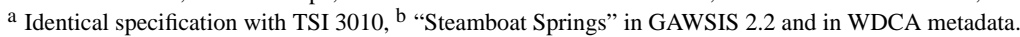

\subsection{Data selection}

A crucial choice is to use either $N$ or $\log _{10}(N)$ as the main property of the study. There are many reasons to support the log-scale as the natural scale of study for aerosol particle number concentration trends:

1. Usually, one is interested more in the relative trends of the property in question (with units of $\% \mathrm{yr}^{-1}$ ), as this is the approach which enables comparison in the trend from stations with different background concentrations. If the trend is calculated from a linear scale of $N$ (with units of $\mathrm{cm}^{-3} \mathrm{yr}^{-1}$ ), one must then choose the concentration that is used to divide the linear trend to get the relative trend. This additional degree of freedom can produce some bias in the resulting trend. For agreement with the companion paper methodology, where logarithmic transformation was not used for practical reasons, we also calculated similar linear-to-log relative trends using the sample median as the divisor, when using the Mann-Kendall (MK) methodology (see Sect. 2.5).

2. The log-scale is arguably more natural to study aerosol concentrations. Not only is the shape of the histogram more balanced (often close to normal) on a log-scale, but also individual outlier values have much less effect on the trend fitting in logarithmic space. This is especially important for the generalized least squares (GLS) method (Sect. 2.5.1), which like any least squares method, can be sensitive to extreme outlier values.

3. The aerosol-cloud interaction is more connected to the relative changes in the aerosol properties than to the absolute changes of the concentrations. This is evident in many of the semi-empirical CCN-to-CDNC (cloud droplet number concentration) formulas presented in the literature, where the CDNC count is typically related to the logarithm of the $\mathrm{CCN}$ number concentration 
(e.g. Gultepe and Isaac, 1999), or directly to the relative change of the $\mathrm{CCN}$ number concentration (Platnick and Twomey, 1994).

Based on these reasons, we concentrated on the relative trends of the $N$, calculated using $\log _{10}(N)$ datasets. The additional $\mathrm{MK}$ trends were calculated using a linear scale, resulting in $\mathrm{cm}^{-3} \mathrm{yr}^{-1}$ trends, which were then changed to relative trends by dividing by the sample median.

Another issue is the climate relevance of the resulting trend. CCN are only a small part of the total aerosol particle number concentration, and accurate knowledge of concentrations in the accumulation mode and at the larger end of Aitken mode can not be directly obtained from the $N$ data only. As mentioned previously, strong connections exist between modelled number concentrations of particles and their concentrations in the CCN particle size range (Spracklen et al., 2010; Reddington et al., 2011). In this paper, we have used stations reporting size distribution datasets, and we studied the size-dependence of the observed trends by calculating both $N 20$ concentrations (particle diameters from 20 to $500 \mathrm{~nm}$ ) and $N 100$ concentrations (diameters from 100 to $500 \mathrm{~nm}$ ), with the assumption that $N 100$ will represent the $\mathrm{CCN}$ sized particle number concentration.

\subsection{Data handling and pre-processing}

The data were divided into several datasets for the use of this study. In GLS trend analyses (Sect. 2.5.1) two kinds of daily means were calculated for logarithmic datasets, one with the whole day data, and the other using only the periods between 21:00-09:00 of local solar time. This was done to test the sensitivity of trends to day-time nucleation bursts, and to potentially generate trends that are more dominated by trends in the Aitken and/or accumulation mode.

The station at Pallas (PAL) has frequent inside-cloud situations, which can affect the aerosol particle number concentrations, as the data used were from instruments that did not use a total aerosol inlet. For this reason, we followed the approach from Kivekäs et al. (2009), and pre-screened the data for only the periods where the local visibility was above $3000 \mathrm{~m}$, indicating cloud-free conditions. At other stations with frequent inside-cloud situations, a heated total aerosol inlet was used, and the in-cloud situations should not affect the detected concentrations.

The daily means were, in the case of $N$, a suitable parameter to use, as the tests done with the full hourly time series did not show strong variation between hourly and daily mean values for the $N$ trends. This is not necessarily true for many other aerosol properties and thus we do not support this methodology without checking the dataset sensitivity for such averaging. For MK trends, hourly values were used for consistency with the companion paper methodology.

\subsubsection{Quality assurance}

The quality assurance protocol for this study was similar to the companion paper. As some of the data were from nonGAW stations, a similar procedure as in the GAW station quality assurance was adapted for this data. The overall procedure of the data checking was

- The data were initially collected and pre-screened by the institutions responsible for the dataset. These data were submitted to the GAW database at NILU and then downloaded for the use in this study.

- A questionnaire about changes in instruments, operating procedures, and data handling was sent to the data providers. The information from this questionnaire was used to detect potential disruptions in the dataset.

- The submitted data were independently visually inspected in $\log$ and in linear scales by the main author of this work. Questions, especially concerning rapid or un-characteristic changes in concentration or variability were then sent to the data providers for resolution.

- If a change in the instrumental conditions was coincident with a clear change in the concentration level or variance, the data of the changed period were not included in the analysis. In many cases, the disruption was only temporary, and the data were again accepted when the signal returned to close-to-normal level after the next instrument check-up.

Notably, this quality assurance removed significant parts of the data from some of the stations. The updated versions of the datasets were submitted to the GAW-WDCA database in NILU EBAS (http://ebas.nilu.no/) for more general use by other studies. The resulting improvement in the quality of data highlights the benefits of close interaction between data users and data providers to long-term monitoring.

\subsection{Trends and confidence intervals}

Aerosol number concentrations are not usually normally distributed in either concentration or size space. Traditionally, the size distribution function is assumed to consist of relatively log-normal modes (Seinfeld and Pandis, 2006). Similarly, the aerosol number and mass concentration are also generally relatively log-normally distributed (van Dingenen et al., 2004; Asmi et al., 2011). There are some cases however, where this does not necessarily hold, such as mountain and coastal sites, where particle number histograms can be formed from several (semi)lognormal modes (Asmi et al., 2011)

A common feature in almost all atmospheric datasets, and in particular aerosol number concentrations, is a high autocorrelation (persistence) of the concentrations (Asmi et al., 2011). In essence this means that the variability of concentration time series is affected by long wavelength (slow) 
Table 2. Trends of aerosol number concentrations for the entire period available for each dataset. Trends for daily means are calculated in logarithmic space for the GLS method (Generalized Least Squares). The confidence intervals (CIs) for the GLS method are calculated using an autoregressive bootstrap (ARB) method, showing the 5th and 95th percentile CIs. Mann-Kendall trends and significances are calculated in linear space, and the relative trends are obtained by dividing the absolute trend by the sample median concentration. Night time trends are calculated from night time (21:00-09:00 local (solar) time) means. The bolded trends have statistically significant sign (CIs are the same sign for GLS trends, for MK trends the trend passes the significance test with $p<0.05$, see companion paper for MK test details). For data quality assurance, see text.

\begin{tabular}{|c|c|c|c|c|c|c|c|c|c|c|}
\hline \multirow{3}{*}{$\begin{array}{l}\text { Dataset } \\
\mathrm{NMY}\end{array}$} & \multirow{3}{*}{$\begin{array}{l}\text { Region } \\
\text { ANT }\end{array}$} & \multirow{3}{*}{$\begin{array}{l}\text { Period } \\
1995-2010\end{array}$} & \multicolumn{4}{|c|}{ Trend of daily means $\left(\mathrm{yr}^{-1}\right)$} & \multicolumn{3}{|c|}{ Trend of night-time means $\left(\mathrm{yr}^{-1}\right)$} & \multirow{3}{*}{ Notes } \\
\hline & & & \multirow{2}{*}{$\begin{array}{r}\text { GLS } \\
0.2 \%\end{array}$} & \multicolumn{2}{|c|}{$\mathrm{CI}(\mathrm{ARB})$} & \multirow{2}{*}{$\begin{array}{r}\text { MK } \\
0.8 \%\end{array}$} & \multirow{2}{*}{$\begin{array}{c}\text { GLS } \\
0.4 \%\end{array}$} & \multicolumn{2}{|c|}{$\mathrm{CI}(\mathrm{ARB})$} & \\
\hline & & & & $-0.5 \%$ & $1.0 \%$ & & & $-0.3 \%$ & $1.1 \%$ & \\
\hline SPO1 & ANT & 1974-1988 & $-2.2 \%$ & $-3.4 \%$ & $-1.0 \%$ & $-4.6 \%$ & $-2.2 \%$ & $-3.4 \%$ & $-1.0 \%$ & HA \\
\hline $\mathrm{SPO} 2$ & & 1989-2011 & $-1.5 \%$ & $-2.4 \%$ & $-0.5 \%$ & $-3.4 \%$ & $-1.5 \%$ & $-2.3 \%$ & $-0.6 \%$ & \\
\hline НPB & EUR & $1995-2011$ & $-0.2 \%$ & $-1.1 \%$ & $-0.2 \%$ & $0.3 \%$ & $-0.1 \%$ & $-0.5 \%$ & $0.4 \%$ & \\
\hline JFJ & EUR & $1997-2010$ & $-1.0 \%$ & $-2.6 \%$ & $0.5 \%$ & $0.5 \%$ & $-0.4 \%$ & $-1.1 \%$ & $0.2 \%$ & HA \\
\hline MHD & EUR & $2000-2010$ & $0.7 \%$ & $-2.7 \%$ & $3.9 \%$ & $-0.5 \%$ & $1.3 \%$ & $-2.5 \%$ & $4.7 \%$ & 1 \\
\hline PAL & EUR & 1996-2010 & $-1.5 \%$ & $-2.6 \%$ & $-0.4 \%$ & $-1.0 \%$ & $-1.3 \%$ & $-2.2 \%$ & $-0.2 \%$ & \\
\hline BND & $\mathrm{NCA}$ & 1994-2011 & $-2.7 \%$ & $-3.5 \%$ & $-1.9 \%$ & $-4.8 \%$ & $-2.9 \%$ & $-3.7 \%$ & $-2.2 \%$ & \\
\hline BRW & $\mathrm{NCA}$ & 1998-2011 & $0.4 \%$ & $-1.0 \%$ & $2.4 \%$ & $1.1 \%$ & $0.9 \%$ & $-0.7 \%$ & $2.5 \%$ & \\
\hline SGP & $\mathrm{NCA}$ & 1997-2011 & $-2.6 \%$ & $-3.3 \%$ & $-1.8 \%$ & $-2.3 \%$ & $-2.6 \%$ & $-3.3 \%$ & $-2.0 \%$ & \\
\hline SPL & SPL & 1998-2010 & $-2.4 \%$ & $-4.5 \%$ & $-1.1 \%$ & $-2.6 \%$ & $-2.5 \%$ & $-4.3 \%$ & $-1.3 \%$ & HA \\
\hline MLO & SWP & 1999-2011 & $-4.0 \%$ & $-4.7 \%$ & $-3.3 \%$ & $-3.1 \%$ & $-4.5 \%$ & $-5.3 \%$ & $-3.6 \%$ & HA \\
\hline SMO1 & SWP & 1977-1992 & $-3.7 \%$ & $-4.3 \%$ & $-3.0 \%$ & $-4.0 \%$ & $-3.5 \%$ & $-4.0 \%$ & $-2.9 \%$ & \\
\hline SMO2 & & $1992-2011$ & $-1.1 \%$ & $-1.7 \%$ & $-0.4 \%$ & $-0.3 \%$ & $-1.2 \%$ & $-1.9 \%$ & $-0.4 \%$ & 2 \\
\hline \multicolumn{11}{|c|}{ Size distribution datasets } \\
\hline HYY20 & EUR & 1996-2011 & $-1.3 \%$ & $-1.9 \%$ & $-0.8 \%$ & $-1.0 \%$ & $-1.2 \%$ & $-1.8 \%$ & $-0.6 \%$ & \\
\hline HYY100 & & & $-1.5 \%$ & $-2.5 \%$ & $-0.5 \%$ & $-1.9 \%$ & $-1.6 \%$ & $-2.6 \%$ & $-0.7 \%$ & \\
\hline VAR20 & EUR & $1997-2011$ & $-2.9 \%$ & $-3.7 \%$ & $-2.1 \%$ & $-4.6 \%$ & $-2.8 \%$ & $-3.7 \%$ & $-1.8 \%$ & \\
\hline VAR100 & & & $-3.5 \%$ & $-4.8 \%$ & $-2.4 \%$ & $-3.2 \%$ & $-3.6 \%$ & $-4.8 \%$ & $-2.6 \%$ & \\
\hline PAL20 & EUR & 2000-2010 & $0.1 \%$ & $-1.0 \%$ & $2.6 \%$ & $0.0 \%$ & $0.7 \%$ & $-1.0 \%$ & $2.1 \%$ & 3,4 \\
\hline PAL100 & & & $2.6 \%$ & $0.5 \%$ & $5.3 \%$ & $5.0 \%$ & $2.9 \%$ & $0.7 \%$ & $5.2 \%$ & 3,4 \\
\hline MPZ20 & EUR & 1997-1998 and & $0.4 \%$ & $-0.4 \%$ & $1.2 \%$ & $1.6 \%$ & $0.5 \%$ & $-0.2 \%$ & $1.4 \%$ & 5 \\
\hline MPZ100 & & 2004-2010 & $0.2 \%$ & $-0.8 \%$ & $1.3 \%$ & $2.7 \%$ & $0.5 \%$ & $-0.6 \%$ & $1.9 \%$ & 5 \\
\hline VHL20 & EUR & 2001-2011 & $-1.5 \%$ & $-2.9 \%$ & $-0.1 \%$ & $-0.4 \%$ & $-1.5 \%$ & $-3.1 \%$ & $-0.1 \%$ & \\
\hline VHL100 & & & $-2.6 \%$ & $-4.0 \%$ & $-0.1 \%$ & $-0.8 \%$ & $-2.2 \%$ & $-4.3 \%$ & $-0.2 \%$ & \\
\hline
\end{tabular}

$\mathrm{HA}=$ High altitude station, ANT $=$ Antarctica, EUR $=$ Europe, NCA = North America and Caribbean, SWP $=$ South West Pacific. ${ }^{1}$ Several instances of exceeding the instrumental measurement limits in the daytime datasets due to coastal nucleation - gap in 2001. ${ }^{2}$ Long gap from 1994 to 2004 - significant chance of error or bias in the analysis, especially as the instrument changed from $2004 \mathrm{on}$. See Table $1 .{ }^{3}$ Several data gaps in the last years of dataset, potential bias to trend. ${ }^{4}$ Station commonly in-cloud. Trends given for cloud-screened datasets. ${ }^{5}$ Long gap from 1998 to 2002 - significant chance of error or bias in the analysis.

changes, and thus each measurement of aerosol properties in the typical measurement time interval is strongly connected to the previous measurements. This has an effect on the information content of the time series and can invalidate many statistical methods that assume independence of the data (von Storch and Zwiers, 1999). In the context of aerosol trends, this makes trend fitting using ordinary least squares (OLS) methods less reliable.

The concept of a trend has an implicit assumption that the time series of observations $x(i), t(i), i=1 \ldots n$ can be sensibly broken down to a (log) linear long-term change (the trend) and short-term noise or periodic variability. As particle number concentrations have typically high autocorrelation, it is useful to include such effects into the data model. The simplest way is to model the data as lag-1 autoregressive process.
Then, as the seasonality plays a strong role in the aerosol particle number concentrations, it is useful to take such effects into account as a stationary seasonal signal $\Omega(t(i))$. The time series is thereby separated to:

$x(i)=\beta_{1}+\beta_{2} t(i)+\Omega(t(i))+\alpha r(i-1)+S(i) e(i)$

where $\beta_{1}$ and $\beta_{2}$ are the trend parameters (base level and slope), $\Omega(t)$ is the seasonal signal, $\alpha$ is the lag-1 autocorrelation coefficient, $S$ is the magnitude of the random noise component, $e$ is the random noise term and $r(i-1)$ is the total noise term (autocorrelation and random noise) of the previous observation $(i-1)$.

Two methods for trend fitting were used: (1) the nonparametric Mann-Kendall trend analysis (MK) is based on rank and is associated with the Sen's slope estimator allowing 
detection of the presence of a trend and its magnitude, respectively (Gilbert, 1987). To correct for autocorrelation in the data, a pre-whitening procedure was applied to the data prior to the trend detection (Wang and Swail, 2001; Zhang and Zwiers, 2004). Both methods were applied to linear space slope determination, which was then converted to relative trends by dividing by the sample median. The specifics of the MK methodology and related significance testing are described in the companion paper. (2) The generalized least square (GLS) trends, with either autoregressive or block bootstrap confidence intervals for statistical significance testing. The GLS approach is adapted from Mudelsee (2010) with minor modifications (notably assuming that variability and autocorrelation will not change strongly in the time series, i.e. $\alpha$ and $S$ are assumed to be time invariant, and by adding the seasonal components), and thus we only describe the method in an abbreviated form. Interested readers are recommended to read Mudelsee (2010) Chapters 2, 3 and 4, with references therein.

\subsubsection{Generalized least squares (GLS) trends}

GLS fit parameters $\boldsymbol{\beta}$ (two trend parameters and four seasonal parameters) are calculated by minimizing the sum of squares to get the trend parameters $\boldsymbol{\beta}$ (Mudelsee, 2010, algorithm 4.3):

$S S=(\boldsymbol{x}+\mathbf{T} \boldsymbol{\beta})^{\prime} \mathbf{V}^{-1}(\boldsymbol{x}+\mathbf{T} \boldsymbol{\beta})$,

where the data array $\boldsymbol{x}$ is defined as:

$\boldsymbol{x}=\left[\begin{array}{c}x(1) \\ \vdots \\ x(n)\end{array}\right]$

the time array $\mathbf{T}$ as:

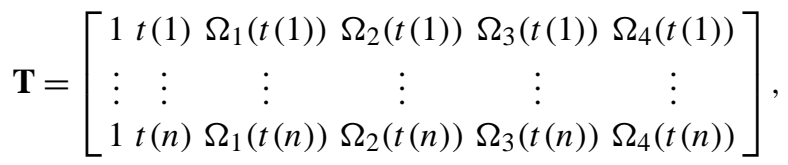

where seasonal components $\Omega_{1 \ldots 4}(t)$ are four seasonal sinusoidal components defined as:

$\Omega_{1}=\sin \left(\frac{2 \pi t}{(1 \mathrm{yr})}\right), \Omega_{2}=\sin \left(\frac{4 \pi t}{(1 \mathrm{yr})}\right)$,

$\Omega_{3}=\cos \left(\frac{2 \pi t}{(1 \mathrm{yr})}\right), \Omega_{4}=\cos \left(\frac{4 \pi t}{(1 \mathrm{yr})}\right)$.

The covariance $(n, n)$ matrix $\mathbf{V}$ was defined as:

$\mathbf{V}\left(i_{1}, i_{2}\right)=\hat{S}^{2} \exp \left(-\frac{\left|t\left(i_{1}\right)-t\left(i_{2}\right)\right|}{\hat{\tau}^{\prime}(\alpha)}\right)$

where $\hat{S}$ is the standard deviation of the analysed signal, and $\tau^{\prime}(\alpha)$ is the estimated persistence time approximation (Mudelsee, 2010, Chapter 2) with autocorrelation bias correction from Kendall (1954). In our case, the solution for the minimization of Eq. (2) was obtained using the Matlab function Iscov, which uses either Cholesky or orthogonal decomposition of $\mathbf{V}$, depending on the condition of $\mathbf{V}$ (MathWorks, Inc., 2010).

The GLS fit first approximated the $\boldsymbol{\beta}$ factors directly from the sample, using Eq. (2) with autocorrelation and standard deviation of the time series. Using the obtained trend and seasonal signal, the time series was then split into trend, seasonal signal and the residuals (Eq. 1). The GLS fitting was then iterated using the autocorrelation and standard deviation of the residuals to update the $\mathbf{V}$, until the relative difference between the trends from the last two iterations was below $1 \%$ of the trend slope.

\subsubsection{Bootstrap confidence intervals $(\mathrm{CI})$}

Fitting a trend does not itself tell if there is a significant linear (or log-linear) change in the time series. Strong seasonality and noise of the datasets makes the trend detection difficult, potentially generating spurious trends and tendencies, even when using non-parametric methods. One approach to estimate the significance of the detected trends is by using statistical significance tests. The traditional statistical tests, assuming a specific shape of the distribution and independent measurements, are not directly applicable to aerosol particle number concentration datasets. In this paper, we concentrate on the bootstrap methods to evaluate the trend significance.

In this context, "bootstrapping" means that we estimate the robustness of the observed trend by calculating similar trends from re-sampled datasets, which are generated by randomly sampling (with replacement) the noise terms of the data model (Eq. 1). Figure 1 shows the two methods used for such re-sampled dataset generation in a schematic way.

The autoregressive bootstrap (ARB) approach used is directly applied from the Mudelsee (2010), algorithm 3.5. By randomly selecting (with replacement) the last part of the Eq. (1) (e) and re-building the datasets with the original autocorrelation, trend and seasonality, a semi-random realization of the time series is created.

For studies of individual monthly trends, we used a moving block substitution bootstrap process (MBB) (Mudelsee, 2010, algorithm 3.3). This approach is natural for the monthly data, as the monthly datasets provide compact blocks of the time series that contain a significant part of the time series autocorrelation (persistence), and are short enough to have large enough pool of blocks for the resampling. MBB calculates the GLS trend as above for each month and constructs the bootstrapped time series by using randomized selections of the month-sized blocks of residuals from different years. In monthly data analyses, no seasonal fitting was implemented (i.e. the $\Omega$ terms in Eq. (4) were absent).

In both cases, the same trend analysis method as in the original GLS fit was then done to the bootstrapped time series (using the original co-variance matrix) to obtain 


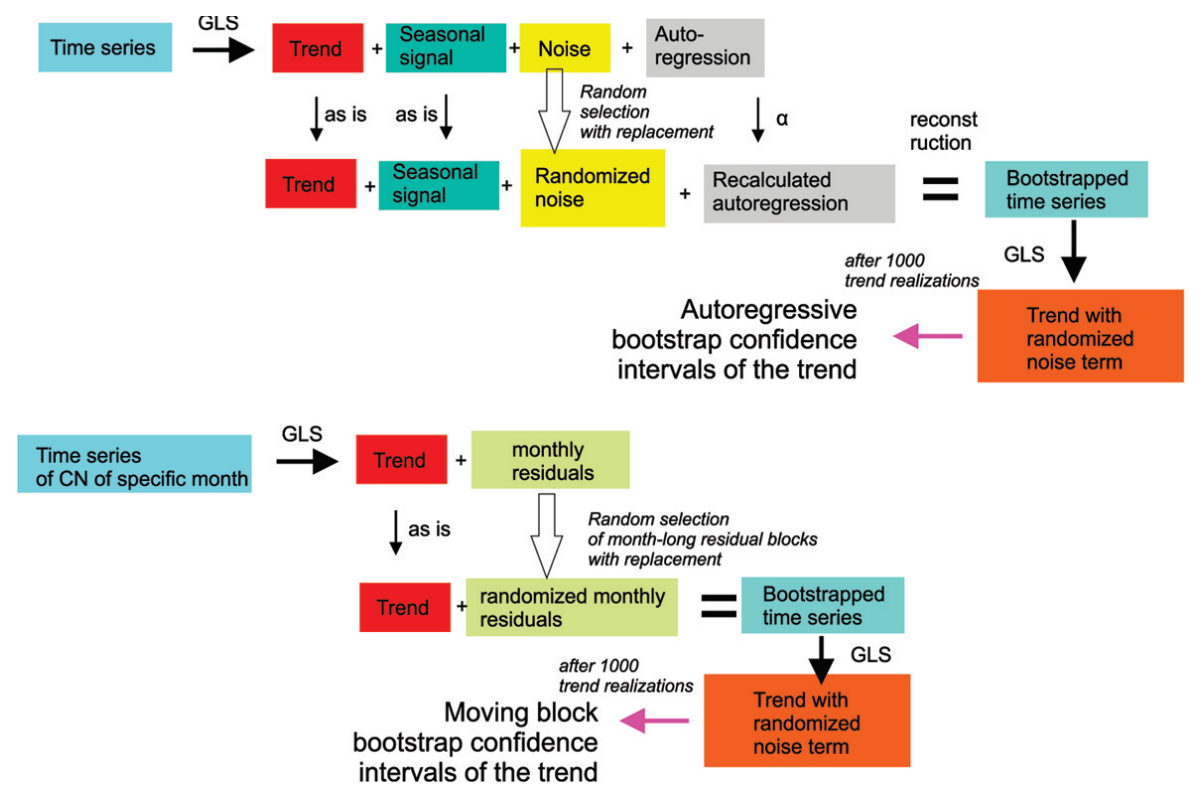

Fig. 1. Block diagram of GLS-ARB (above) and GLS-MBB (below) methods used for confidence interval generation. In the GLS-ARB, the time series is divided into trend, seasonal, autoregressive and noise parts. By randomly selecting the noise terms, and reconstructing the time series, another realization of the trend fitting can be made. From a number of these realizations, an ARB confidence interval is constructed. For trends of specific months, the GLS-MBB method randomly selected the residual term of the GLS fit in one-month long blocks (i.e. replacing the original residual with random year's residual for the month in question). From these random realizations, a MBB confidence interval is constructed. The methods are adapted from Mudelsee (2010).

bootstrapped trend parameters $\boldsymbol{\beta}^{\prime}$. The process was then repeated 1000 times in the analyses done in this paper to get the distribution of $\boldsymbol{\beta}^{\prime}$ s, and the confidence intervals were then determined by selecting the 5th and 95th percentiles of this set. If the confidence interval of the slopes does not include zero (i.e. $\mathrm{CI}$ is either in the increasing or decreasing trend side), we consider the trend "sign" to be "statistically significant" (s.s.) at the $95 \%$ confidence level.

\section{Results}

The trends of number concentrations for the whole period of study are shown in Table 2 and in graphical form in Figs. 24. The time periods are not the same for all stations, but an overall negative trend is evident for stations where a statistically significant trend was observed, with one exception: CCN-sized (N100) particle number concentrations at Pallas in Northern Finland. Notably, there is a lack of trend at the Central European sites JFJ, HPB and MPZ, although in the case of MPZ, the trend significance and even direction could be severely affected by the large gap in the data. The lack of trend in JFJ is in agreement with Collaud Coen et al. (2007).

The trends of night-time concentrations follow the overall trends very closely for most stations, showing that the trends in general are not very sensitive to diurnal variations in aerosol particle number concentrations. This suggests that either the trends are controlled by longer-lived aerosol pop- ulations in the Aitken and accumulation modes rather than by $N$ formed during nucleation bursts, or that the frequency and/or intensity of such bursts are relatively unchanging over the period studied.

The Mace Head (MHD) station data for the daily averages should be considered with some caution, as relatively persistent and strong coastal nucleation events had the tendency to create number concentrations that were above the upper detection limit of the instrument. This could result in biased trends, especially as the instrument upper limit had clearly changed several times during the measurement period. Nevertheless, night-time trends for this station have almost the same long-term behaviour as the whole-day trends, even though there were no such nucleation peaks in the nighttime time series. This indicates that the lack of a detected trend is robust with respect to nucleation events, or that the signals from the day-time nucleation peaks were diminished by the upper detection limit of the instrument.

The MK and GLS/ARB methods of trend/significance testing agreed closely, especially in the sign and significance of the detected trends. The MK method gave s.s. trends, which the GLS/ARB method did not only in two cases (BRW and MHD), even though the MK trends were within the ARB confidence interval. The MK method gives slightly larger absolute trend values than GLS/ARB for the $N$ datasets, although this result is not universal. Overall, the relatively good agreement between the two methods on the trend sign, and to 
Table 3. $N$ trends for the period 2001-2010 for stations with at least $9 \mathrm{yr}$ of data in that period. Notation as in Table 2. Trends are shown only for the all-day means, but as in Table 2, the differences with night-time mean trends are minimal.

\begin{tabular}{lrrrr}
\hline & \multicolumn{4}{c}{ Trend of daily means $\left(\mathrm{yr}^{-1}\right)$} \\
\cline { 2 - 5 } Dataset & GLS & \multicolumn{2}{c}{ CI (ARB) } & MK \\
\hline NMY & $\mathbf{3 . 3 \%}$ & $1.7 \%$ & $5.1 \%$ & $\mathbf{3 . 7 \%}$ \\
SPO2 & $\mathbf{4 . 8 \%}$ & $0.7 \%$ & $9.4 \%$ & $\mathbf{1 . 7} \%$ \\
HPB & $0.4 \%$ & $-0.2 \%$ & $1.1 \%$ & $0.3 \%$ \\
JFJ & $\mathbf{- 2 . 2 \%}$ & $-3.3 \%$ & $-1.0 \%$ & $-\mathbf{1 . 6} \%$ \\
MHD & $0.9 \%$ & $-2.6 \%$ & $4.8 \%$ & $0.9 \%$ \\
PAL & $\mathbf{- 2 . 6 \%}$ & $-4.3 \%$ & $-0.9 \%$ & $-\mathbf{3 . 0} \%$ \\
BND & $\mathbf{- 4 . 6 \%}$ & $-6.0 \%$ & $-3.3 \%$ & $-\mathbf{7 . 2} \%$ \\
BRW & $-0.4 \%$ & $-2.9 \%$ & $2.5 \%$ & $-1.3 \%$ \\
SGP & $\mathbf{- 5 . 7 \%}$ & $-6.6 \%$ & $-4.5 \%$ & $-\mathbf{5 . 3 \%}$ \\
SPL & $\mathbf{- 5 . 6 \%}$ & $-7.7 \%$ & $-4.3 \%$ & $-\mathbf{7 . 3 \%}$ \\
MLO & $\mathbf{- 2 . 1 \%}$ & $-3.0 \%$ & $-1.3 \%$ & $-\mathbf{3 . 5} \%$ \\
& Size distribution datasets & \\
HYY20 & $\mathbf{- 2 . 8 \%}$ & $-3.7 \%$ & $-1.9 \%$ & $-\mathbf{3 . 3 \%}$ \\
HYY100 & $\mathbf{- 2 . 4 \%}$ & $-3.8 \%$ & $-0.7 \%$ & $-\mathbf{1 \%}$ \\
PAL20 & $0.4 \%$ & $-0.3 \%$ & $1.3 \%$ & $0.0 \%$ \\
PAL100 & $\mathbf{0 . 3 \%}$ & $-0.8 \%$ & $1.4 \%$ & $\mathbf{5 . 0 \%}$ \\
VAR20 & $\mathbf{- 3 . 0 \%}$ & $-4.2 \%$ & $-1.3 \%$ & $-\mathbf{1 . 6 \%}$ \\
VAR100 & $\mathbf{- 3 . 2 \%}$ & $-5.1 \%$ & $-1.2 \%$ & $-\mathbf{2 . 9 \%}$ \\
VHL20 & $\mathbf{- 1 . 5 \%}$ & $-2.9 \%$ & $-0.1 \%$ & $-0.4 \%$ \\
VHL100 & $\mathbf{- 2 . 2 \%}$ & $-4.2 \%$ & $-0.1 \%$ & $-\mathbf{0 . 8} \%$ \\
\hline
\end{tabular}

a lesser degree the trend magnitude, gives credibility to the technical robustness of the observed trends.

\subsection{Trends of 2001-2010}

We also calculated the trends for a shorter period, 2001 through 2010 (inclusive). This timeframe was chosen as a relatively long period when $N$, scattering, and light absorption data from many stations were available, to enable comparison of trends for different aerosol properties. The trends for $N$ are shown in Table 3. Notable changes from the all-time trends are the increase of concentrations at the Antarctic stations (obvious increase in SPO in Fig. 2a) and s.s. decrease at JFJ. Overall, the trends in this period agreed with the longerperiod trends, which may be attributed to the fact that the full record from some stations was not very different from the period 2001-2010.

\subsection{Monthly trends}

Strong seasonality of aerosol number concentrations in many locations makes the long-term trends of different months interesting to study. The potential of biogenic organic emissions, or possibly seasonal anthropogenic emissions, to affect number concentrations can influence the trends. We used the GLS/MBB method of trend evaluation and bootstrap confidence intervals to detect the trends for each month. A similar analysis was also done with the MK methodology, but the results are not shown here, because they were similar in statistical significance.

The results are shown in Fig. 3. The stations in the central USA have a similar decreasing overall trend but different seasonal behaviour, with BND decreases concentrated in the fall months, SGP decreases more in the spring-summer period, and SPL having no month with statistical significance in agreement with Hallar et al. (2011). The Pacific stations have very stable decreasing trends with no clear seasonal effects. In Antarctica, the apparent decrease of the South Pole datasets is especially clear from September to May ( $\mathrm{SH}$ summer) for SPO1, but no clear seasonal differences in the trends could be seen at NMY. In Northern Europe, the decreases are concentrated to wintertime for all PAL, VAR20 and HYY20 datasets. The PAL20 dataset does not agree in its seasonal or overall trend with the other datasets, most likely due the data gaps (see next section). The VHL station in Southern Sweden shows much weaker winter-time decreasing signal than other Nordic stations, probably due the influence of longrange transport from Central Europe. In Central Europe, both MPZ and HPB seem to have decreases of concentrations during wintertime, but as this is balanced by increases in other seasons (especially in the MPZ spring-summer trends), the overall trends are minimal. The high-alpine JFJ shows a decreasing concentration tendency in summer (significant decrease in June) when the site is partially influenced by planetary boundary layer air (see also companion paper). At the coastal station MHD, the only s.s. trend seems be during fall, when the concentrations are decreasing.

\section{Discussion}

\subsection{Trends of particle number concentrations vs. trends of "CCN"}

As mentioned earlier, different particle sizes have different impacts on the climate system. Particles larger than $100 \mathrm{~nm}$ have much greater chance to act as cloud condensation nuclei and have much higher scattering coefficients. Long-term measurements of the number size distribution make it possible to study the trends of different aerosol sizes separately. Unfortunately, long-term DMPS time series are only available from European sites, 3 of 5 in Finland, which reduces the applicability of these trends in a global context. Combined with night-time means, the time series can provide some information on the direct impact of the new particle formation on the long trends (i.e. on the effect of the "peak" of the particle number concentration spectra during the nucleation event), and on the possibility to generalize the $N$ trends to CCN. The $N 20$ and N100 GLS/ARB trends agreed almost perfectly on most available datasets on trend direction, magnitude and significance. For Northern European conditions, the trends seem to be uniform over the size distributions, and 

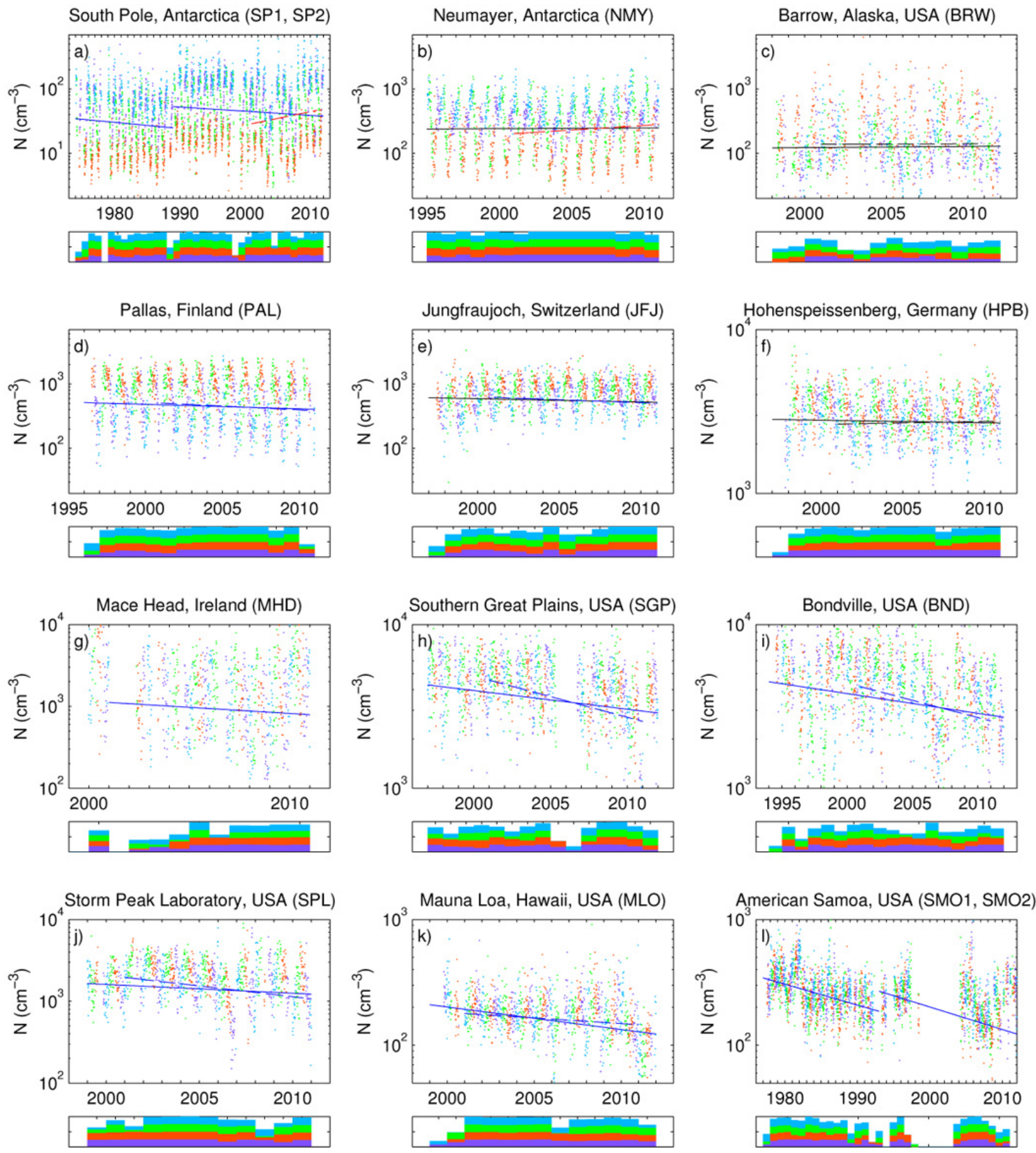

Seasonal data coverage

Seasonal data coverage

Seasonal data coverage

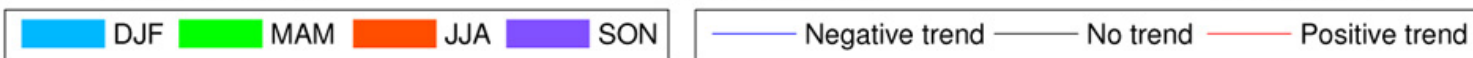

Fig. 2. Generalized least squares trends of $N$ at the GAW stations. Different colours of the dots show the time series split into 4 seasons as shown in the legend (DJF: December-February, MAM: March-May, JJA: June-August and SON:September-November). Lines show the GLS trend (increasing: red, decreasing: blue, no s.s. trend: black). Each plot includes the GLS trend and, where possible, the trend for period of 2001-2010 (dashed lines). Data coverage per season is shown below each subplot. For SPO and SMO separate trends for datasets with different instruments are shown. 


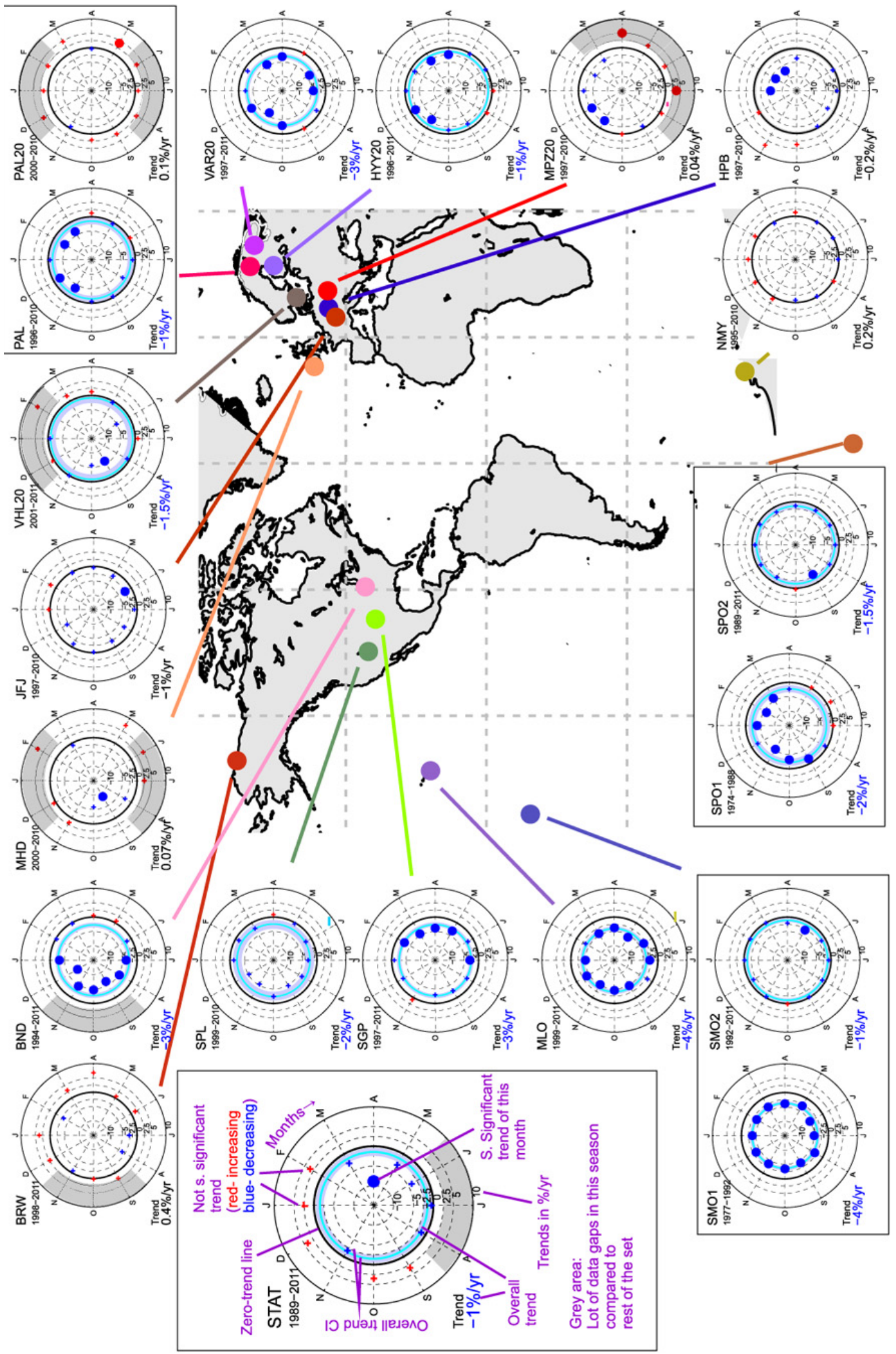

Fig. 3. Monthly trends of $N$ and $N 20$ time series, calculated from daily mean values with GLS/MBB methodology for all data available. See insert for symbol explanation. Symbols and circles inside of the zero line show decreasing $N$ trends (blue) and outside increasing $N$ trends (red). Black circles and small symbols denote no s.s. trend. 
the observed decrease in the $N 20$ is applicable to " $\mathrm{CCN}$ " concentrations in this area and for this period. The general lack of difference between all-day and night-time mean trends demonstrates that the observed trends are robust representations of the relatively long-lived part of the size distribution, or that the frequency and intensity of new particle formation events are relatively constant. The similar longterm behaviour of $N 20$ and N100 is in agreement with earlier studies of short time ( $2 \mathrm{yr}$ ) comparisons of $30-100 \mathrm{~nm}$ and $100-500 \mathrm{~nm}$ size class concentrations at European stations, where both concentrations showed a general tendency to follow each other (Fig. 13 in Asmi et al., 2011).

Measurements at PAL are a particular case in this context, as the station has both $N$ and size distribution $(N 20$ and N100) measurements. The calculated trends do not agree well (Table 2), as the size distribution trends are either increasing or indicate no trend, while the total $N$ is decreasing. This could be problematic, as the size cut-off difference between $N 20$ and $N$ concentrations is relatively small, $10 \mathrm{~nm}$, and a large difference in trends suggests high sensitivity to the smallest particle sizes. However, we found that a possible reason for this apparent discrepancy is data availability, as the later years of the Pallas DMPS measurements had long gaps during periods with unusually low concentrations for the season, which effectively removed these low concentrations from the trend analysis. This was tested by replacing the missing $N 20$ measurements with $N$ measurements (which should actually overestimate the $N 20$ concentrations for the period), which results in significantly decreasing $N 2 O$ concentrations for the measurement period, similar to the $N$ time series. In another test, we only did trend analyses for both $N 20$ and $N$ for the period when both were available. In that test, both time series failed to produce a s.s. trend. This is not to say that $N 20$ and $N$ are the same series though, even though there is clear similarity in their behaviour $\left(R^{2}=0.61\right.$, $n=2446$, for daily mean $\log _{10}(N)$ ). A similar test could not be done for the $N 100$ concentrations. However, this analysis shows that gaps of even few months can affect the trend fitting for such relatively short time series, especially if the seasonality and overall variability is high.

\subsection{Trend reliability}

The sensitivity of trend fitting to data gaps, as evidenced in the PAL station data above, can be problematic in some of the observed trends. As we do not have similar comparison datasets for other stations, different amounts of gaps in different seasons and different parts of the datasets can cause a bias in the observed trends. Graphs under each station's time series in Figs. 2 and 4 show the seasonal data coverage for each dataset. Highly seasonal datasets (usually located in extreme latitudes) are perhaps more sensitive to data gaps, especially in the monthly trends (Fig. 3). In the overall trend calculation, both MK and GLS methods included a fitted seasonal component. This seasonal component fitting makes the trends less sensitive to seasonal gaps, although the trends will still be sensitive to gaps that happen during unusually low or high concentrations for that time of the year. This was the reason for the trend sign difference at PAL, and there is no clear way to make sure the same has not happened at stations with many (or long) data gaps. Even in the best case, the lack of one season's data could still affect the fitting of the seasonal component, influencing the detected trends indirectly.

The monthly trends do not have seasonal components for obvious reasons. This makes them more sensitive to the lack of data for specific years, especially at either end of the dataset. By going through the data coverage per season in Figs. 2 and 4 and trying to find seasons with particularly low representation in the dataset, or very one-sided datasets (e.g., consisting of mostly data from the beginning of the measurement period), we identified some specific times of the year when the monthly trends could be affected by data gaps. These are shown in Fig. 3 as gray arcs. The gaps cast doubt on the the spring-summer increase at MPZ and on the BND autumn decrease. The above discussion is, however, a subjective analysis of potential errors due the data gaps, and the true errors, especially at stations with long gaps in the middle, remain unknown.

\subsection{Comparison with optical and mass property trends}

In the companion paper, the long-term trends of several aerosol optical properties are studied. Unfortunately, the long time series of aerosol particle number concentrations and optical measurements do not have high overlap. Table 4 shows the MK trends of $N$ and optical properties for the period 2001-2010 for stations with data available on $N$ and either scattering and/or absorption. Globally, the trends do not have strong similarities. Only the continental US stations (BND and SGP) show some similarity between $N$ and scattering, but that could easily be coincidental. Similarly, there is little evidence of strong similarity between $N$ and absorbing aerosol trends for this period. As the scattering measurements are more sensitive to the aerosol number concentration in the larger end of the accumulation mode than to smaller particles, this casts some doubt on the possibility to generalize $N$ trends to trends in larger particle sizes. When the similarity between all-day and night-time $N$ trends is also considered, the poor agreement of $N$ and optical property trends suggest that the $N$ trends are controlled by particles in the larger range of the Aitken mode and smaller range of the accumulation mode, i.e. ca. $50-150 \mathrm{~nm}$ diameter. Another interpretation of the differences could be that the $N$ trends are more sensitive to the emissions than are the scattering or absorption coefficients. From these comparisons of in-situ measurements, it does not seem that the different integral properties of the aerosol population have high agreement in their trends.

Satellite and ground based measurements show s.s. decreasing trends of AOD in Europe and North America since the 
Table 4. Comparison of trends and trend significances between $N$ and optical properties (from companion paper). The period of study is 2001-2010. Only MK trends are shown.

\begin{tabular}{|c|c|c|c|}
\hline Dataset & $\begin{array}{r}\mathrm{CN} \\
\text { Trend } \\
(\mathrm{MK}) \\
\left(\% \mathrm{yr}^{-1}\right)\end{array}$ & $\begin{array}{r}\text { Scattering } \\
\text { coeff. } \\
(\mathrm{MK}) \\
\left(\% \mathrm{yr}^{-1}\right)\end{array}$ & $\begin{array}{r}\text { Abs. } \\
\text { coeff. } \\
(\mathrm{MK}) \\
\left(\% \mathrm{yr}^{-1}\right)\end{array}$ \\
\hline NMY & 3.7 & 2.5 & -2.5 \\
\hline НPB & 0.3 & 1.7 & -3.9 \\
\hline JFJ & -1.6 & -1.2 & -1.0 \\
\hline MHD & 0.9 & 2.7 & -2.0 \\
\hline PAL & -3.0 & -0.9 & - \\
\hline BND & -7.2 & -1.9 & -2.0 \\
\hline BRW & -1.3 & 2.4 & -6.5 \\
\hline SGP & -5.3 & -2.0 & - \\
\hline MLO & -3.5 & 2.7 & 9.0 \\
\hline
\end{tabular}

late 1990's, in general agreement with the $N$ trends shown here (de Meij et al., 2012; Hsu et al., 2012). In the Pacific region, the AOD trends have been increasing in contrast to the $N$ trends. PM mass concentration trends in many parts of Europe have been decreasing during the 1998-2008 period, a feature relatively well captured by regional air quality models (Colette et al., 2011). Similarly, the decrease of sulphate concentrations and deposition in the Continental US are evident (Hand et al., 2012), also shown in the global modelling study of Leibensperger et al. (2012). Although the decreases in Europe and US are similar in N, PM and AOD, this does not necessarily mean that the trends are similar in other periods of time, or different locations. Different aerosol properties have different dominating sources and sinks, and the trends of them might be different. For example, Wang et al. (2012) showed significant differences between $\mathrm{PM}_{2.5}$ and $\mathrm{PM}_{10}$ trends in Europe and US.

\subsection{Possible drivers of aerosol number concentration trends}

This paper provides, for the first time, global information on $N$ trends for all stations reporting at least $10 \mathrm{yr}$ of $N$ data to GAW-WDCA. With few exceptions, the results show a general, significantly decreasing trend, of the order of a few $\% \mathrm{yr}^{-1}$ (max GLS negative trend is $-5.7 \% \mathrm{yr}^{-1}$ at SGP). A full explanation of the causes of these trends would require a chemical transport model with detailed aerosol processes and observed meteorology, which is far beyond the scope of this article. Instead, we explore possible explanations for the trend strengths and directions to assess which are consistent (or inconsistent) with the observations. There is no reason to assume that there would be a single over-arching factor determining the aerosol trends at all stations. All of these analyses were done with data from 2001-2010 (inclusive) only, to include the maximum number of stations and to keep them comparable to each other. This is thus more of a study of behaviour during the past decade, rather than longer-term trends.

The mechanisms compared are:

1. Yu et al. (2012) proposed that increasing air temperatures lead to decreasing trends of aerosol number concentrations. The mechanism was based on the principle of higher temperatures increasing the saturation vapour pressure of the nucleating species, thereby decreasing the nucleation rate and finally the aerosol particle number concentration. As saturation vapour pressures are generally exponentially-dependent on air temperature, the approximate relationship between nucleation rate $(J)$ and temperature trends (tr) would be $\operatorname{tr}(\log (J)) \sim$ $\operatorname{tr}(T)$. As the model calculations in Yu et al. (2012) had a similar (but weaker) response on $N$ as for the nucleation rates, a similar approximate relationship is here assumed to exist between $N$ and $T$ trends as well. Notably, Yu et al. (2012) compared surface temperature trends from an IPCC report with modelled $N$ trends. A modeling study by Merikanto et al. (2009) concluded that most of the aerosol number concentration formed by nucleation, especially for $\mathrm{CCN}$ sizes, are actually formed in the free troposphere (FT). For this reason, we downloaded the RSS MSU satellite monthly mean $\left(2.5^{\circ} \times 2.5^{\circ}\right)$ product of lower troposphere temperatures from http:www.remss.com. The data would then support the $\mathrm{Yu}$ et al. (2012) hypothesis and the Merikanto et al. (2009) result if the linear trend of FT temperatures was similar in magnitude but opposite in sign to the trend of the logarithm of observed $N$ values.

2. In continental areas, surface temperatures have potential impacts on volatile organic compound (VOC) emissions from biogenic sources (Schurgers et al., 2009). Oxidation of VOCs can affect aerosol formation rates (Kulmala et al., 2004a; Paasonen et al., 2010) and mass concentration (Leaitch et al., 2011). Tunved et al. (2006) showed that increase in monoterpene emissions do, at least in the Boreal zone, increases both $N$ and $\mathrm{CCN}$. As the emission rate is related to the exponential of the temperature (as in case I, above), the expected functional form would be $\operatorname{tr}(\log (N)) \sim \operatorname{tr}(T)$. The biosphere is located at the surface, so surface temperatures are the only reasonable comparison. We obtained surface temperature trends directly from the instrumental GISS temperature trends web applet http://data.giss. nasa.gov/gistemp/maps $/{ }^{1}$ (Hansen et al., 2010). A reasonable expectation for this mechanism is that an increase in the regional temperatures would lead to an increase in aerosol particle number concentrations. However, as this process is connected to biogenic emissions

\footnotetext{
${ }^{1}$ with the settings

GHCN_GISS_HR2SST_1200km_Trnd0112_2001_2010
} 
from land vegetation, it should not influence stations in marine or polar environments The temperature-VOC- $N$ relationship can also be much more complex than presented in this analysis. Metzger et al. (2010) presented results suggesting that organic vapours could directly participate in the actual nucleation mechanism, making the functional form potentially much more complex and sensitive to VOC emissions than described above. Another complexity could come from the condensing organics on existing larger particles, increasing coagulation sink of small particles and thus decreasing particle concentrations. These kinds of complex feedbacks are outside of the scope of this analysis.

3. Anthropogenic emissions are, of course, a major source of aerosol particle number concentrations. $\mathrm{SO}_{2}$ is a major precursor of secondary particles, sulphuric acid - the most important species in new particle formation - and sulphates produced from in-cloud oxidation. Changes in primary particles can, however, act in both directions: they can increase the particle number directly, or they can reduce the new particle formation rate by acting as sinks for particles and condensible vapours. We considered these changes by obtaining the $\mathrm{SO}_{2}$ and $\mathrm{PM}_{10}$ emission inventories for the years 2000 2008 from EDGARv4.2 global emission inventory ${ }^{2}$. The timeframe is slightly different than for the $N$ measurements due to limitations of the available emission data, and the data were annual averages, giving only 8 datapoints per pixel. We averaged the annual emission rates over a $0.5 \times 0.5^{\circ}$ grid before trend-fitting for computational reasons. For this mechanism, one would expect the concentrations to have similar trends as the emissions, and thus the comparison was aimed at the question: are the relative trends similar for $N$ and the potential anthropogenic precursors?

4. Aerosols affect the meteorology, but meteorology also affects the aerosol. Besides the temperature effects (1 and 2 above), two other potential meteorological explanations for the aerosol number trends were considered: (i) precipitating clouds are a major sink for the $\mathrm{CCN}$-sized particles, and thus changes in precipitation should also influence the long-term aerosol number concentrations. An increase in rainfall should thus be associated with a decrease in particle concentrations. (ii) Aerosol and aerosol precursor emissions are generally at ground level, but the concentration is affected by the height of the mixed layer. If there is a consistent

\footnotetext{
${ }^{2}$ Downloaded from http://edgar.jrc.ec.europa.eu/overview.php? $\mathrm{v}=42$ as IPCC level 1 datasets, summed for all sectors. Source: European Commission, Joint Research Centre (JRC)/Netherlands Environmental Assessment Agency (PBL). Emission Database for Global Atmospheric Research (EDGAR), release version 4.0. http: //edgar.jrc.ec.europa.eu, 2009.
}

relative change in the mixing layer height, this could lead to relative changes in aerosol concentrations, even when surface emissions are constant. An increase in the general boundary layer heights could also act as a proxy of possibility of incursions of boundary layer air to high altitude stations. To study these two parameters, we collected the "synoptic monthly means" 20012010 datasets of both total precipitation and boundary layer heights ${ }^{3}$ from the ECMWF ERA-INTERIM reanalysis at http://data-portal.ecmwf.int/data/d/interim full_mnth/ (Dee et al., 2011). The monthly means of daily-accumulated total precipitation were assumed to represent changes in regional precipitation of the station, and the boundary layer heights were assumed to represent the changes in the mixing layer behaviour. These proposed mechanisms should not be considered to be exhaustive of the potential effects of the meteorological parameters on $N$ trends. Recently, Tai et al. (2012) showed that the interannual variability of $\mathrm{PM}_{2.5}$ in the US Midwest is strongly correlated with cyclone frequency. Although part of this sensitivity could be captured by the precipitation product of meteorological re-analysis used above, systematic changes in advection would require complex model studies to resolve. Another example of a complexity not considered here is the sensitivity of new particle formation to background aerosol concentration. The below-cloud scavenging of larger particles can radically decrease the coagulation sink of small particles, leading to more prevalent and strong new particle formation events (Kerminen et al., 2001). Thus an increase of precipitation could also increase $N$.

For all the datasets described above, we did a simple ordinary least squares (OLS) trend fit for each map grid point over the period 2001-2010 (2001-2008 for EDGAR emissions), i.e. we assumed that the comparison series are independent and normally distributed. For relative trends, the fit was done to the logarithm of the data. No tests of statistical significance were done for these comparison datasets, and thus the main idea was to identify possible qualitative similarities between $N$ trends and these potential controlling factors. The resulting trends are shown in Fig. 5; as aerosol particles have a life time of approximately one week, we will concentrate on the changes in the regional behaviour of the potential trend drivers.

Free tropospheric temperatures have decreased or stayed the same near almost all of the stations (Fig. 5a), which does not agree with the expectations of case (1) above. We

\footnotetext{
${ }^{3}$ Data were downloaded with times 00:00 and 12:00 with step of $12 \mathrm{~h}$. The monthly means of daily forecast accumulations of precipitation were obtained by summing both monthly values as described in http://www.ecmwf.int/products/data/archive/data_faq.html. The data were re-gridded by the ECMWF dataserver to $1 \times 1$ degree resolution.
} 

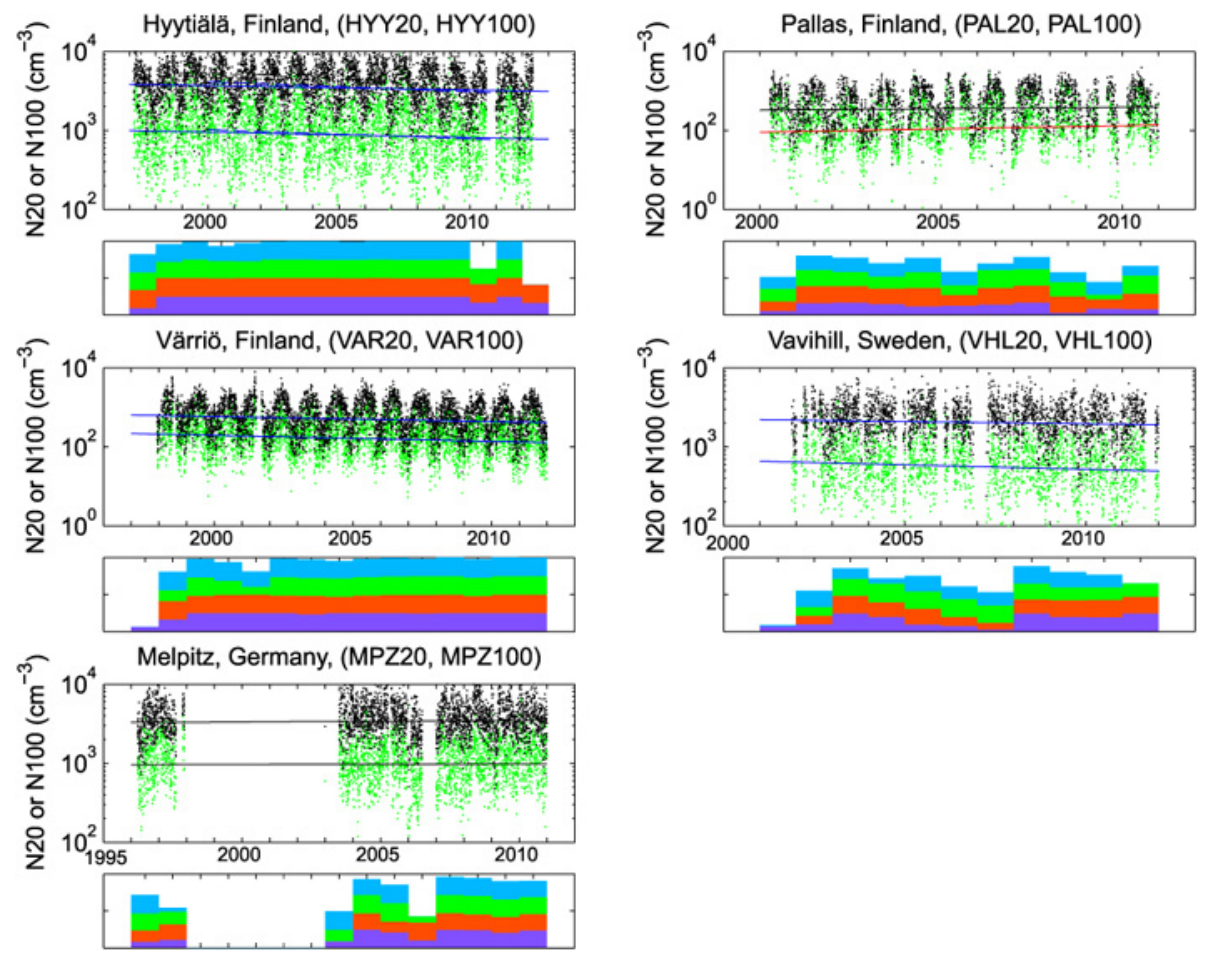

Fig. 4. Trends of size size-specified aerosol concentrations $N 20$ (black dots) and N100 (green dots). The notation is the same as in Fig. 2, except for the dot colour.

can not compare the results near the Antarctic stations due the limitations of the RSS MSU coverage, but for the other stations the qualitative agreement in the trends between FT temperature and $N$ is evident. Even if the nucleation is actually dominated by the surface temperatures, the high similarity between FT temperature trends and surface instrumental trends (Fig. 5b) do not provide support for case (1) for this time period, as the trends are generally in the same direction or non-existent. The disagreement between the spatial variability of different satellite-derived FT temperature products creates some uncertainty in this analysis (Xu and Powell, 2011). The surface temperature trends (Fig. 5b) resemble the $N$ trends at continental sites where mechanism (2) could apply, especially considering that the prevailing winds in Northern Europe are from the western direction. The marine sites do not have visible temperature trends in the GISS dataset, and the similarity between Antarctic $N$ and $T$ trends is most likely co-incidental, as there is no vegetation to emit VOCs in that region. Overall, of the temperature-based trend mechanisms, case (2) seems to have better agreement with the measurements for this time period. However, when the time period studied is increased to cover the period from 1995-2010 (Fig. 6), the picture for the case (2) changes: even though the number concentration trends for this time period are still negative in Northern Europe and the continental US, the surface temperature has actually increased in Northern Europe over the period. This change in the temperature trend, depending on the period studied, but not observed in the $N$ trends, suggests that the overall $N$ trends are not consistently affected by air temperature changes. This results casts doubts on the global explanatory power of both theories (1) and (2) as a dominating effect ${ }^{4}$. Additionally, the locations where the 2000-2010 surface temperature and $N$ trends agree most evidently, central USA and Northern Europe, have most of their $N$ decreases during wintertime - a period of decreased or non-existent BVOC emissions.

According to the EDGARv4.2 inventory, anthropogenic emissions have changed in the period from 2000-2008 (Fig. 5c-d). The trends in $\mathrm{SO}_{2}$ and $\mathrm{PM}_{10}$ emissions in Europe and North America have many similarities with the $N$ trends, especially for $\mathrm{SO}_{2}$. In the Pacific region, increases from shipping emissions do not have similar behaviour as the $N$ trends, suggesting that the trends there are not sensitive to the anthropogenic emissions of these species, or that the inventories are incomplete. The inventoried anthropogenic emissions are zero for Antarctica, but there are indications that emissions from the South Pole base itself might affect

\footnotetext{
${ }^{4}$ We also compared the the $N$ trends with the trends of another instrumental temperature dataset: CRUTEM4v (Jones et al., 2012), which resulted in qualitatively similar results (see Supplement Fig. S1), with the main difference being that the for 19952010 period, the region around Continental US sites had generally no trend in the temperature records.
} 

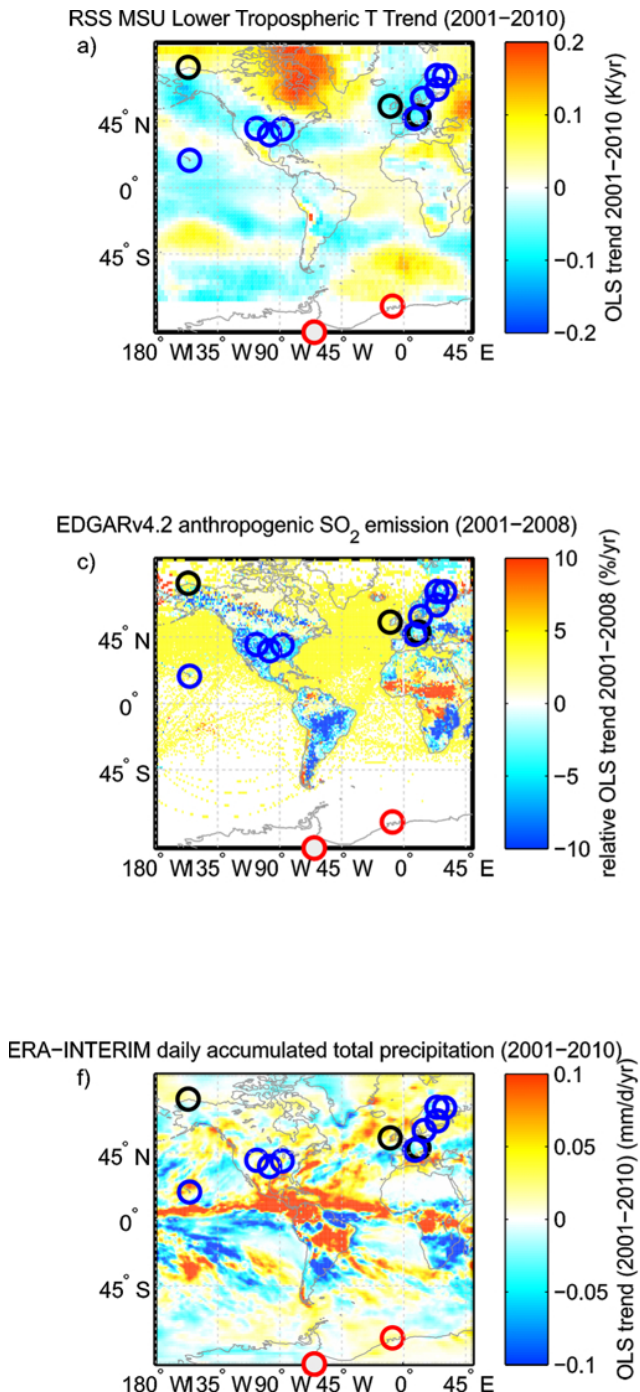
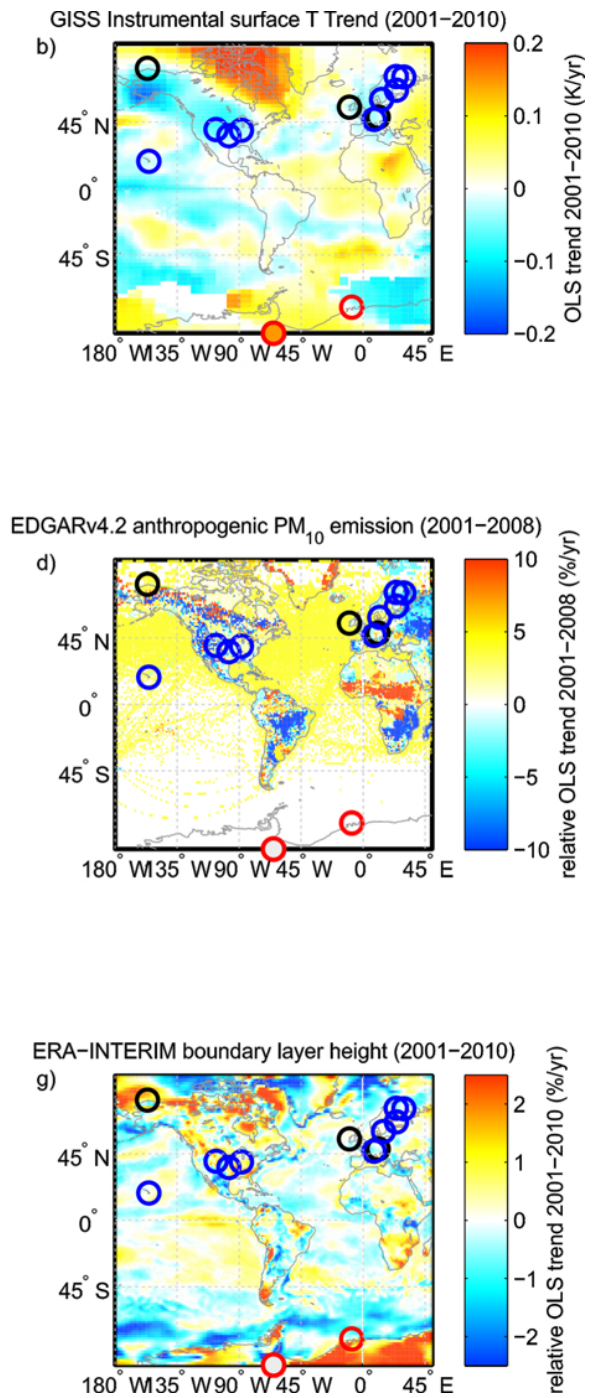

Fig. 5. Comparison of different potential explanatory mechanisms for GLS/ARB $N$ trends 2001-2010, blue symbols indicate statistically significant decreasing trends, red symbols s.s. increasing trends and black symbols indicate no s.s. trend. For DMPS datasets $N 20$ was used. Comparison trends were calculated with OLS. (a) RSS Lower troposphere temperature from satellite microwave sensors; (b) GISS surface instrumental temperature trend; (c-d) EDGARv4.2 emission inventory trends for $\mathrm{SO}_{2}$ and $\mathrm{PM}_{10}$, note the period from 2001-2008; (e-f) ERA-Interim re-analysis trends for 2001-2010 for monthly mean of daily forecast accumulated total precipitation and boundary layer height. South Pole station shown at middle lower edge of the plot.

number concentrations at $\mathrm{SPO}^{5}$. Overall, anthropogenic $\mathrm{SO}_{2}$ emissions generally have similar behaviour as $N$ trends in this period, and we could not find opposing trends between $N$ concentrations and $\mathrm{PM}_{10}$ emissions, making the trend model (III) for $\mathrm{SO}_{2}$ a possible partial explanation of the aerosol particle number concentration trends. Notably, the trends of the $\mathrm{SO}_{2}$ emission datasets are also decreasing in the 19952008 period (not shown), making the anthropogenic influ-

\footnotetext{
${ }^{5}$ Construction of the IceCube neutrino observatory began in winter 2006-2007, which involved a large amount of drilling and snow moving, as the large detectors were buried deep beneath the ice surface. Moreover, the number of personnel at the station (at least over the summer seasons) has increased substantially.
}

ences a potential explanation of the observed $N$ trends on that timescale as well. However, the absence of a decreasing $N$ trend at MPZ and HPB, even with the decrease in Central European $\mathrm{SO}_{2}$ emissions, shows that this process is not necessarily linearly correlated in polluted environments, presumably due to multiple complex feedbacks in aerosol growth and dynamics (Hamed et al., 2010).

Total precipitation trends were generally weakly increasing near the measurement stations (Fig. 5e), and further analysis (not shown) with separate large-scale and convective precipitation did not change this weak connection between the two. The largest changes in total precipitation were concentrated in the tropics, where no long-term measurements 

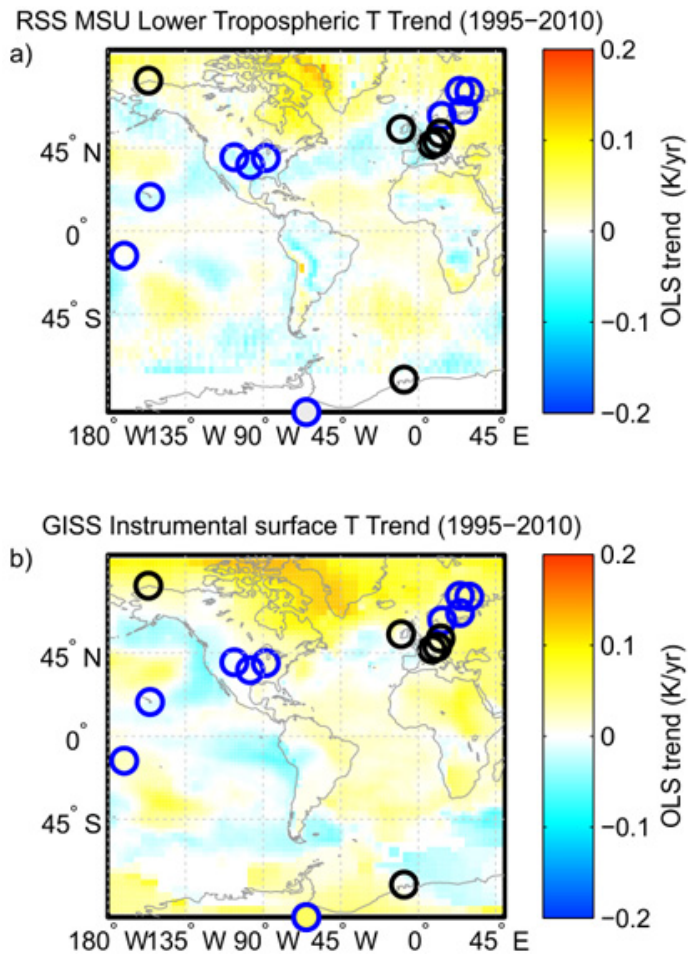

Fig. 6. Same as Fig. 5, but for period of 1995-2010. Note that some of the stations' CN trends are not for the complete period of 19952010, see Table 2 for the maximum coverage.

of $N$ are yet available. Boundary layer heights did not either show high similarity with the observed trends, especially as in most of Europe the boundary layer height actually decreased during this period. We also did not find a similarity of mountain station (JFJ, MLO, SPL) $N$ trends and boundary layer height trends. Overall, we did not find clear evidence of an impact of these meteorological parameters on the $N$ concentration trends.

\section{Conclusions}

Trend analyses showed that the near-surface concentrations of atmospheric aerosol particles decreased at most observation points since the 1990's. These changes are visible and statistically significant in most locations studied in this paper, covering Northern Europe, North America, Antarctica, and the Pacific Ocean. The derived negative relative trends are generally slightly lower in magnitude than the reduction of anthopogenic $\mathrm{SO}_{2}$ emissions over the last decades in $\mathrm{EU}$ and in US. However, the low number of stations with long datasets does not allow us yet to conclude that such decreasing trends are universal, regionally or globally.

Aerosol number concentration trends showed clear seasonal variations, with Northern European stations especially showing decreasing $N$ trends during wintertime. As the wintertime concentrations should also be less influenced by bio- genic sources of aerosol particles and aerosol precursors, this result suggests that the decrease in Northern Europe is more due to anthropogenic sources than biogenic ones. In the central USA, the three stations showed clearly decreasing $N$ trends, although in different seasons. In the Pacific, the observed decreases did not have a seasonal cycle.

At stations where size distribution measurements were available, the trends of number concentrations of over $20 \mathrm{~nm}$ particles and over $100 \mathrm{~nm}$ particles generally agreed very closely with each other, suggesting that, at least for Northern European conditions, the observed decreasing trends are happening for both $N$ and $\mathrm{CCN}$ size ranges.

Comparison with results from the companion paper do not show clear similarities between the $N$ and optical properties trends, although the locations where this comparison could be made was limited. We also observed that gaps in the dataset can affect the resulting trends, especially at locations with large seasonal cycles. Based on this, we can not recommend using short time campaign-type measurements as the basis for trend analyses of aerosol properties, at least without further knowledge of the seasonal and inter-annual variability of $N$ concentrations in the area.

The high level of agreement between the two fitting methods used in this paper demonstrates the technical reliability of the trend fitting procedures. However, the overall reliability of the trends is also dependent on the data availability, which was unfortunately not optimal at some stations. However, due the overall lack of long duration data series, these are the pieces of information we have and they provide us with the only qualified estimations of long-term $N$ behaviour in these environments. Overall, we consider the observed trends to be the best available information on the trends of $N$ at present.

There is no real reason to assume that there is only one process affecting $N$ trends at one station, or that the same process would be effective globally. The low number of stations, and especially the lack of long-duration measurements in Asia and in the tropics, still limits the applicability of this kind of trend analysis for more effective conclusions of the factors affecting global aerosol loadings. The strongest support for the observed decrease in $N$ during 2001-2010 period, of the limited set of potential reasons for these trends that was considered, is the reduction in the anthropogenic sources of aerosols and aerosol precursors, $\mathrm{SO}_{2}$ in particular. Another possible driver could be from the regional cooling of the atmosphere in Europe and Northern America during this period, decreasing the secondary biogenic aerosol mass in these regions. However, further analysis with longer time periods and seasonal variation did not support such a temperature-based effect. We could not find evidence of temperature-nucleation feedback suggested by Yu et al. (2012) based on free tropospheric or surface temperature trends. This does not mean that such processes could not affect the atmosphere in different regions, over different timescales and different periods of time. We could also not find 
clear similarity between $N$ trends and trends of total precipitation or boundary layer height. The two Central European low-land stations did not show statistically significant trends. However, there are decreasing trends in monthly-analysed winter-time concentrations measured at these stations. As the role of biogenic emissions should be lessened during wintertime (making the anthropogenic emissions more prominent), this could indicate a role of human-induced emission decreases also in HPB and MPZ dataset trends, which are masked by biogenic emission increases during the summer. This hypotheses, if true, hints that a simplified one-driver model of aerosol number concentration trends is not adequate, and future analyses of aerosol trend drivers must be able to include competing processes affecting the aerosol concentrations. A rigorous determination of which factors are actually behind the decreasing trends is left to future studies.

The past trends are useful for determining the mechanisms and sources behind the aerosol number concentrations. Until the cause of the trends is better constrained, however, drawing strong conclusions about the future of aerosol number concentrations is not possible. If the anthropogenic influences, suggested by part of the datasets, are really behind these significant decreases in the particle number, and the assumption that $N$ trends are representative of $\mathrm{CCN}$ trends is valid, the strong warming forcing of pollution controls suggested by Brasseur and Roeckner (2005) could have some support from these results. There are indications that, in some areas, this change in emissions has already happened, making this decrease of particle number only of historical importance in those regions (Leibensperger et al., 2012), but the global effects of further air quality controls could still be adverse to climate (Kloster et al., 2008; Makkonen et al., 2012).

Keeping the long time series consistent requires considerable financial and human effort. The trend analyses in this paper and the companion paper clearly show the importance of long time commitments to atmospheric aerosol measurements. Detecting changes in aerosol properties and identifying potential feedback mechanisms resulting from environmental changes will require sustained efforts done within GAW, IMPROVE, EMEP, and GUAN networks, supporting activities such as EUCAARI (Kulmala et al., 2011), and continuous support to aerosol observing infrastructures such as EUSAAR or ACTRIS in the EU. Currently, there are aerosol particle number concentration time series from 27 stations, and 14 stations with size distribution datasets in the EBAS database (http://ebas.nilu.no). Most of these measurements are ongoing, and in about $5 \mathrm{yr}$ they start to be long enough to qualify for trend analyses. However, even with this increased data availability, there is and will be still a clear inadequacy in the measurement network density in many areas of the world, which limits the assessment of aerosol variability at the global scale, and makes it even harder to increase our understanding of future changes in the atmosphere.

\section{Supplementary material related to this article is available online at: http://www.atmos-chem-phys.net/13/ 895/2013/acp-13-895-2013-supplement.pdf.}

Acknowledgements. The research leading to these results has received funding from the European Union Seventh Framework Programme (FP7/2007-2013) under grant agreement no. 262254 (ACTRIS) as well as from the EU FP6 project European Supersites for Atmospheric Aerosol Research (EUSAAR) and the EU FP5 project Construction, use and delivery of an European aerosol database (CREATE). The GAW aerosol data are archived at and available from the World Data Centre for Aerosol (WDCA) located at the Norwegian Institute for Air Research (NILU). The GAW-WDCA data are hosted in the EBAS database (http://ebas.nilu.no/), an infrastructure shared with other frameworks targeting atmospheric aerosol properties, such as the European Monitoring and Evaluation Programme (EMEP) and the European Aerosols, Clouds, and Trace gases Research InfraStructure Network (ACTRIS). The ERA-INTERIM re-analysis data were obtained from the The European Centre for Medium-Range Weather Forecasts (ECMWF). The GISS temperature trends are from http://data.giss.nasa.gov/ gistemp/maps/. MSU data are produced by Remote Sensing Systems and sponsored by the NOAA Climate and Global Change Program. Data are available at www.remss.com. The authors wish to thank the Finnish Centre for Scientific Computing (CSC) for computing resources. The support of the Finnish Center of Excellence in Physics, Chemistry, Biology and Meteorology of Atmospheric Composition and Climate change is acknowledged. We thank the International Foundation High Altitude Research Stations Jungfraujoch and Gornergrat (HFSJG), which made it possible to carry out the experiments at the High Altitude Research Station at the Jungfraujoch. The JFJ operational measurements were supported by MeteoSwiss within the Swiss program of the Global Atmosphere Watch (GAW) of the World Meteorological Organization. The measurements at Melpitz, as part of the German Ultrafine Aerosol Network (GUAN), were co-funded by the German Federal Ministry for the Environment, Nature Conservation and $\mathrm{Nu}$ clear Safety grant F\&E 370343200 (Titles: "Erfassung der Zahl feiner und ultrafeiner Partikel in der Aussenluft" and "Trendanalysen gesundheitsgefährdender Fein- und Ultrafeinstaubfraktionen unter Nutzung der im German Ultrafine Aerosol Network (GUAN) ermittelten Immissionsdaten durch Fortführung und Interpretation der Messreihen"). W. B. thanks Birgit Wehner and Thomas Tuch for their involvement in collecting TDMPS data at Melpitz. The authors appreciate the dedication, commitment, and effort of Randolph Borys, Douglas Lowenthal, Ian McCubbin, and Peter Atkins towards the long-term measurements of aerosol concentration at Storm Peak Laboratory (SPL). Instrumentation at Storm Peak Laboratory used in this analysis was purchased via a grant AGS-0079486 from the US National Science Foundation. The authors would like to thank the numerous, but unfortunately unnamed technical and scientific staff members of the stations included in these analyses, working in the last decades to make the stations operable.

The authors also like to thank the two anonymous reviewers for their useful and perceptive comments on the manuscript.

Edited by: M. C. Facchini 


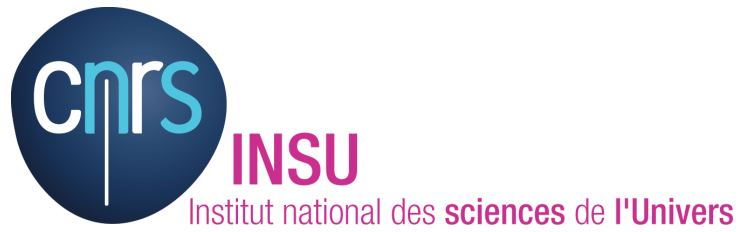

The publication of this article is financed by CNRS-INSU.

\section{References}

Aitken, J.: On improvements in the apparatus for counting the dust particles in the atmosphere, Nature, 16, 134-172, 1889.

Asmi, A., Wiedensohler, A., Laj, P., Fjaeraa, A.-M., Sellegri, K., Birmili, W., Weingartner, E., Baltensperger, U., Zdimal, V., Zikova, N., Putaud, J.-P., Marinoni, A., Tunved, P., Hansson, H.C., Fiebig, M., Kivekäs, N., Lihavainen, H., Asmi, E., Ulevicius, V., Aalto, P. P., Swietlicki, E., Kristensson, A., Mihalopoulos, N., Kalivitis, N., Kalapov, I., Kiss, G., de Leeuw, G., Henzing, B., Harrison, R. M., Beddows, D., O’Dowd, C., Jennings, S. G., Flentje, H., Weinhold, K., Meinhardt, F., Ries, L., and Kulmala, M.: Number size distributions and seasonality of submicron particles in Europe 2008-2009, Atmos. Chem. Phys., 11, 55055538, doi:10.5194/acp-11-5505-2011, 2011.

Birmili, W., Berresheim, H., Plass-Dülmer, C., Elste, T., Gilge, S., Wiedensohler, A., and Uhrner, U.: The Hohenpeissenberg aerosol formation experiment (HAFEX): a long-term study including size-resolved aerosol, $\mathrm{H}_{2} \mathrm{SO}_{4}, \mathrm{OH}$, and monoterpenes measurements, Atmos. Chem. Phys., 3, 361-376, doi:10.5194/acp-3-361-2003, 2003.

Birmili, W., Weinhold, K., Nordmann, S., Wiedensohler, A., Spindler, G., Müller, K., Herrmann, H., Gnauk, T., Pitz, M., Cyrys, J., Flentje, H., Nickel, C., Kulhbusch, T., Lschau, G., Haase, D., Meinhardt, F., Schwerin, A., Ries, L., and Wirtz, K.: Atmospheric aerosol measurements in the German Ultrafine Aerosol Network (GUAN) - Part 1: Soot and particle number distributions, Gefahrstoffe Reinhalt. Luft, 69, 137-145, 2009.

Bodhaine, B. A.: Aerosol measurements at four background sites, J. Geophys. Res., 88, 10753-10768, 1983.

Borys, R. D. and Wetzel, M. A.: Storm peak laboratory: A research, teaching, and service facility for the atmospheric sciences, Bull. Amer. Meteor. Soc., 78, 2115-2123, doi:10.1175/15200477(1997)078;2115:SPLART ¿2.0.CO;2, 1997.

Boulon, J., Sellegri, K., Venzac, H., Picard, D., Weingartner, E., Wehrle, G., Collaud Coen, M., Bütikofer, R., Flückiger, E., Baltensperger, U., and Laj, P.: New particle formation and ultrafine charged aerosol climatology at a high altitude site in the Alps (Jungfraujoch, 3580 m a.s.1., Switzerland), Atmos. Chem. Phys., 10, 9333-9349, doi:10.5194/acp-10-9333-2010, 2010.

Brasseur, G. P. and Roeckner, E.: Impact of improved air quality on the future evolution of climate, Geophys. Res. Lett., 32, L23704, doi:10.1029/2005GL023902, 2005.

Charlson, R. J.: Atmospheric visibility related to aerosol mass concentration: review, Environ. Sci. Technol., 3, 913-918, doi:10.1021/es60033a002, 1969.

Colette, A., Granier, C., Hodnebrog, Ø., Jakobs, H., Maurizi, A., Nyiri, A., Bessagnet, B., D’Angiola, A., D’Isidoro, M., Gauss, M., Meleux, F., Memmesheimer, M., Mieville, A., Rouill, L., Russo, F., Solberg, S., Stordal, F., and Tampieri, F.: Air quality trends in Europe over the past decade: a first multi-model assessment, Atmos. Chem. Phys., 11, 11657-11678, doi:10.5194/acp11-11657-2011, 2011.

Collaud Coen, M., Weingartner, E., Nyeki, S., Cozic, J., Henning, S., Verheggen, B., Gehrig, R., and Baltensperger, U.: Long-term trend analysis of aerosol variables at the highalpine site Jungfraujoch, J. Geophys. Res., 112, D13213, doi:10.1029/2006JD007995, 2007.

Collaud Coen, M., Andrews, E., Asmi, A., Baltensperger, U., Bukowiecki, N., Day, D., Fiebig, M., Fjaeraa, A., Flentje, H., Hyvärinen, A., Jefferson, A., Jenning, S. G., Kouvarakis, G., Lihavainen, H., Lund Myhre, C. L., Malm, W. C., Mihapopoulos, N., Molenar, J. V., O’Dowd, C., Ogren, J., Schichtel, B. A., Sheridan, P., Virkkula, A., Weingartner, E., Weller, R., and Laj, P.: Aerosol decadal trends - Part 1: In-situ optical measurements at GAWand IMPROVE stations, Atmos. Chem. Phys., 13, 869-894, doi:10.5194/acp-13-869-2013, 2013.

de Meij, A., Pozzer, A., and Lelieveld, J.: Trend analysis in aerosol optical depths and pollutant emission estimates between 2000 and 2009, Atmospheric Environment, 51, 75-85, doi:10.1016/j.atmosenv.2012.01.059, 2012.

Dee, D. P., Uppala, S. M., Simmons, A. J., Berrisford, P., Poli, P., Kobayashi, S., Andrae, U., Balmaseda, M. A., Balsamo, G., Bauer, P., Bechtold, P., Beljaars, A. C. M., van de Berg, L., Bidlot, J., Bormann, N., Delsol, C., Dragani, R., Fuentes, M., Geer, A. J., Haimberger, L., Healy, S. B., Hersbach, H., H.-L., E. V., Isaksen, L., KCEllberg, P., Kšhler, M., Matricardi, M., McNally, A. P., Monge-Sanz, B. M., Morcrette, J.-J., Park, B.-K., Peubey, C., de Rosnay, P., Tavolato, C., Thžpaut, J.-N., and Vitart, F.: The ERA-Interim reanalysis: configuration and performance of the data assimilation system, Quat. J. R. Meteorol. Soc., 137, 553597, doi:10.1002/qj.828, 2011.

Dockery, D. W. and Pope, C.: Acute respiratory effects of particulate air pollution, Annu. Rev. Public. Health, 15, 107-132, 1994

Donaldson, K., Li, X., and MacNee, W.: Ultrafine (nanometre) particle mediated lung injury, J. Aerosol Sci., 29, 553-560, 1998.

Gilbert, R. O.: Statistical Methods for Environmental Pollution Monitoring, Van Nostrand Reinhold Company, New York, 1987.

Global Atmosphere Watch: Aerosol measurement procedures guidelines and recommendations, Tech. Rep. 153, WMO/GAW, Geneva, CH, no. 153, WMO TD no. 1178, 2003.

Gultepe, I. and Isaac, G. A.: Scale effects on averaging of cloud droplet and aerosol number concentrations: observations and models, J. Climate, 12, 1268-1279, doi:10.1175/15200442(1999)012;1268:SEOAOC $22.0 . C O ; 2,1999$.

Hallar, A. G., Lowenthal, D. H., Chirokova, G., Borys, R. D., and Wiedinmyer, C.: Persistent daily new particle formation at a mountain-top location, Atmos. Environ., 45, 4111-4115, doi:10.1016/j.atmosenv.2011.04.044, 2011.

Hamed, A., Birmili, W., Joutsensaari, J., Mikkonen, S., Asmi, A., Wehner, B., Spindler, G., Jaatinen, A., Wiedensohler, A., Korhonen, H., Lehtinen, K. E. J., and Laaksonen, A.: Changes in the production rate of secondary aerosol particles in Central Europe in view of decreasing $\mathrm{SO}_{2}$ emissions between 1996 and 2006, Atmos. Chem. Phys., 10, 1071-1091, doi:10.5194/acp-10-10712010, 2010.

Hand, J. L., Schichtel, B. A., Malm, W. C., and Pitchford, M. L.: Particulate sulfate ion concentration and $\mathrm{SO}_{2}$ emission trends in the United States from the early 1990's through 2010, 
Atmos. Chem. Phys., 12, 10353-10365, doi:10.5194/acp-1210353-2012, 2012

Hansen, J., Ruedy, R., Sato, M., and Lo, K.: Global surface temperature change, Rev. Geophys., 48, RG4004, doi:10.1029/2010RG000345, 2010.

Hsu, N. C., Gautam, R., Sayer, A. M., Bettenhausen, C., Li, C., Jeong, M. J., Tsay, S.-C., and Holben, B. N.: Global and regional trends of aerosol optical depth over land and ocean using SeaWiFS measurements from 1997 to 2010, Atmos. Chem. Phys., 12, 8037-8053, doi:10.5194/acp-12-8037-2012, 2012.

IPCC: Climate Change 2007, The Physical Science Basis, Contribution of Working Group I to the Fourth Assessment Report of the Intergovernmental Panel on Climate Change, Cambridge University Press, New York, 2007.

Jaenicke, R.: Is atmospheric aerosol an aerosol?, A look at sources and variability, Faraday Discuss., 137, 235-243, doi:10.1039/B701095H, 2008.

Jones, P. D., Lister, D. H., Osborn, T. J., Harpham, C., Salmon, M., and Morice, C. P.: Hemispheric and large-scale land-surface air temperature variations: An extensive revision and an update to 2010, J. Geophys. Res, 117, D05127, doi:10.1029/2011JD017139, 2012.

Kendall, M.: Note on bias in the estimation of autocorrelation, Biometrica, 30, 403-404, 1954.

Kerminen, V. M., Pirjola, L., and Kulmala, M.: How signifigantly does coagulation scavenging limit atmospheric particle production?, J. Geophys. Res., 106, 24119-24125, 2001.

Kerminen, V.-M., Paramonov, M., Anttila, T., Riipinen, I., Fountoukis, C., Korhonen, H., Asmi, E., Laakso, L., Lihavainen, H., Swietlicki, E., Svenningsson, B., Asmi, A., Pandis, S. N., Kulmala, M., and Petäjä, T.: Cloud condensation nuclei production associated with atmospheric nucleation: a synthesis based on existing literature and new results, Atmos. Chem. Phys., 12, $12037-$ 12059, doi:10.5194/acp-12-12037-2012, 2012.

Kivekäs, N., Kerminen, V.-M., Raatikainen, T., Vaattovaara, P., Laaksonen, A., and Lihavainen, H.: Physical and chemical characteristics of aerosol particles and cloud-droplet activation during the Second Pallas Cloud Experiment (Second PaCE), Boreal Env. Res., 14, 515-526, 2009.

Kloster, S., Dentener, F., Feichter, J., Raes, F., van Aardenne, J., Roeckner, E., Lohmann, U., Stier, P., and Swart, R.: Influence of future air pollution mitigation strategies on total aerosol radiative forcing, Atmos. Chem. Phys., 8, 6405-6437, doi:10.5194/acp-86405-2008, 2008.

Komppula, M., Lihavainen, H., Hatakka, J., Paatero, J., Aalto, P., Kulmala, M., and Viisanen, Y.: Observations of new particle formation and size distributions at two different heights and surroundings in subarctic area in northern Finland, J. Geophys. Res., 108, D9, doi:10.1029/2002JD002939, 2003.

Kulmala, M., Suni, T., Lehtinen, K. E. J., Dal Maso, M., Boy, M., Reissell, A., Rannik, U., Aalto, P., Keronen, P., Hakola, H., Bäck, J., Hoffmann, T., Vesala, T., and P., H.: A new feedback mechanism linking forests, aerosols, and climate, Atmos. Chem. Phys., 4, 557-562, doi:10.5194/acp-4-557-2004, 2004a.

Kulmala, M., Vehkamäki, H., Petäjä, T., Maso, M. D., Lauri, A., Kerminen, V.-M., Birmili, W., and McMurry, P.: Formation and growth rates of ultrafine atmospheric particles: a review of observations, J. Aerosol Sci., 35, 143-176, doi:10.1016/j.jaerosci.2003.10.003, 2004b.
Kulmala, M., Asmi, A., Lappalainen, H. K., Baltensperger, U., Brenguier, J.-L., Facchini, M. C., Hansson, H.-C., Hov, Ø., O'Dowd, C. D., Pöschl, U., Wiedensohler, A., Boers, R., Boucher, O., de Leeuw, G., Denier van der Gon, H. A. C., Feichter, J., Krejci, R., Laj, P., Lihavainen, H., Lohmann, U., McFiggans, G., Mentel, T., Pilinis, C., Riipinen, I., Schulz, M., Stohl, A., Swietlicki, E., Vignati, E., Alves, C., Amann, M., Ammann, M., Arabas, S., Artaxo, P., Baars, H., Beddows, D. C. S., Bergström, R., Beukes, J. P., Bilde, M., Burkhart, J. F., Canonaco, F., Clegg, S. L., Coe, H., Crumeyrolle, S., D’Anna, B., Decesari, S., Gilardoni, S., Fischer, M., Fjaeraa, A. M., Fountoukis, C., George, C., Gomes, L., Halloran, P., Hamburger, T., Harrison, R. M., Herrmann, H., Hoffmann, T., Hoose, C., Hu, M., Hyvärinen, A., Hõrrak, U., Iinuma, Y., Iversen, T., Josipovic, M., Kanakidou, M., Kiendler-Scharr, A., Kirkevåg, A., Kiss, G., Klimont, Z., Kolmonen, P., Komppula, M., Kristjánsson, J.-E., Laakso, L., Laaksonen, A., Labonnote, L., Lanz, V. A., Lehtinen, K. E. J., Rizzo, L. V., Makkonen, R., Manninen, H. E., McMeeking, G., Merikanto, J., Minikin, A., Mirme, S., Morgan, W. T., Nemitz, E., O’Donnell, D., Panwar, T. S., Pawlowska, H., Petzold, A., Pienaar, J. J., Pio, C., Plass-Duelmer, C., Prévôt, A. S. H., Pryor, S., Reddington, C. L., Roberts, G., Rosenfeld, D., Schwarz, J., Seland, Ø., Sellegri, K., Shen, X. J., Shiraiwa, M., Siebert, H., Sierau, B., Simpson, D., Sun, J. Y., Topping, D., Tunved, P., Vaattovaara, P., Vakkari, V., Veefkind, J. P., Visschedijk, A., Vuollekoski, H., Vuolo, R., Wehner, B., Wildt, J., Woodward, S., Worsnop, D. R., van Zadelhoff, G.-J., Zardini, A. A., Zhang, K., van Zyl, P. G., Kerminen, V.-M., S Carslaw, K., and Pandis, S. N.: General overview: European Integrated project on Aerosol Cloud Climate and Air Quality interactions (EUCAARI); integrating aerosol research from nano to global scales, Atmos. Chem. Phys., 11, 13061-13143, doi:10.5194/acp11-13061-2011, 2011.

Laakso, L., Hussein, T., Aarnio, P., Komppula, M., Hiltunen, V., Viisanen, Y., and Kulmala, M.: Diurnal and annual characteristics of particle mass and number concentrations in urban, rural and Arctic environments in Finland, Atmos. Environ., 37, 262-2641, doi:10.1016/S1352-2310(03)00206-1, 2003.

Leaitch, W. R., Macdonald, A. M., Brickell, P. C., Liggio, J., Sjostedt, S. J., Vlasenko, A., Bottenheim, J. W., Huang, L., Li, S.-M., Liu, P. S., Toom-Sauntry, D., Hayden, K. A., Sharma, S., Shantz, N. C., Wiebe, H. A., Zhang, W., Abbatt, J. P., Slowik, J. G., Chang, R. Y.-W., Russell, L. M., Schwartz, R. E., Takahama, S., Jayne, J. T., and Ng, N. L.: Temperature response of the submicron organic aerosol from temperate forests, Atmos. Environ., 45, 6696-6704, doi:10.1016/j.atmosenv.2011.08.047, 2011.

Leibensperger, E. M., Mickley, L. J., Jacob, D. J., Chen, W.-T., Seinfeld, J. H., Nenes, A., Adams, P. J., Streets, D. G., Kumar, N., and Rind, D.: Climatic effects of 1950-2050 changes in US anthropogenic aerosols; Part 2: Climate response, Atmos. Chem. Phys., 12, 3349-3362, doi:10.5194/acp-12-3349-2012, 2012.

Liu, B. Y. H. and Kim, C. S.: On the counting efficiency of condensation nuclei counters, Atmos. Environ., 11, 1097-1100, 1977.

Lohmann, U. and Feichter, J.: Global indirect aerosol effects: a review, Atmos. Chem. Phys., 5, 715-737, doi:10.5194/acp-5-7152005, 2005.

Mäkelä, J. M., Dal Maso, M., Pirjola, L., Keronen, P., Laakso, L., Kulmala, M., and Laaksonen, A.: Charasteristics of the atmospheric particle formation events observed at a boreal forest site 
in southern Finland, Boreal Env. Res., 5, 299-313, 2000.

Makkonen, R., Asmi, A., Korhonen, H., Kokkola, H., Järvenoja, S., Räisänen, P., Lehtinen, K. E. J., Laaksonen, A., Kerminen, V.M., Järvinen, H., Lohmann, U., Bennartz, R., Feichter, J., and Kulmala, M.: Sensitivity of aerosol concentrations and cloud properties to nucleation and secondary organic distribution in ECHAM5-HAM global circulation model, Atmos. Chem. Phys., 9, 1747-1766, doi:10.5194/acp-9-1747-2009, 2009.

Makkonen, R., Asmi, A., Kerminen, V.-M., Boy, M., Arneth, A., Hari, P., and Kulmala, M.: Air pollution control and decreasing new particle formation lead to strong climate warming, Atmos. Chem. Phys., 12, 1515-1524, doi:10.5194/acp-12-15152012, 2012.

MathWorks, Inc.: Matlab user manual for R2010a, 2010.

McFiggans, G., Artaxo, P., Baltensperger, U., Coe, H., Facchini, M. C., Feingold, G., Fuzzi, S., Gysel, M., Laaksonen, A., Lohmann, U., Mentel, T. F., Murphy, D. M., O’Dowd, C. D., Snider, J. R., and Weingartner, E.: The effect of physical and chemical aerosol properties on warm cloud droplet activation, Atmos. Chem. Phys., 6, 2593-2649, doi:10.5194/acp-6-25932006, 2006.

McMurry, P. H.: The history of condensation nucleus counters, Aerosol Sci. Technol., 33, 297-322, 2000.

Merikanto, J., Spracklen, D. V., Mann, G. W., Pickering, S. J., and Carslaw, K. S.: Impact of nucleation on global CCN, Atmos. Chem. Phys., 9, 8601-8616, doi:10.5194/acp-9-8601-2009, 2009.

Metzger, A., Verheggen, B., Dommen, J., Duplissy, J., Prevot, A. S. H., Weingartner, E., Riipinen, I., Kulmala, M., Spracklen, D. V., Carslaw, K. S., and Baltensperger, U.: Evidence for the role of organics in aerosol particle formation under atmospheric conditions, P. Natl. A. Sci., 107, 6646-6651, doi:10.1073/pnas.0911330107, 2010.

Mudelsee, M.: Climate Time Series Analysis, vol. 42 of Atmospheric and Oceanographic Sciences Library, Springer, Heidelberg, 2010.

Nyeki, S., Kalberer, M., Lugauer, M., Weingartner, E., Petzold, A., Schršder, F., Colbeck, I., and Baltensperger, U.: Condensation nuclei $(\mathrm{CN})$ and ultrafine $\mathrm{CN}$ in the free troposphere to $12 \mathrm{~km}$ : A case study over the Jungfraujoch high-alpine research station, Geophys. Res. Lett., 26, 2195-2198, 1999.

Ortega, I. K., Suni, T., Boy, M., Grönholm, T., Manninen, H. E., Nieminen, T., Ehn, M., Junninen, H., Hakola, H., Hellén, H., Valmari, T., Arvela, H., Zegelin, S., Hughes, D., Kitchen, M., Cleugh, H., Worsnop, D. R., Kulmala, M., and Kerminen, V.-M.: New insights into nocturnal nucleation, Atmos. Chem. Phys., 12, 4297-4312, doi:10.5194/acp-12-4297-2012, 2012.

Paasonen, P., Nieminen, T., Asmi, E., Manninen, H. E., Petäjä, T., Plass-Dülmer, C., Flentje, H., Birmili, W., Wiedensohler, A., Hõrrak, U., Metzger, A., Hamed, A., Laaksonen, A., Facchini, M. C., Kerminen, V.-M., and Kulmala, M.: On the roles of sulphuric acid and low-volatility organic vapours in the initial steps of atmospheric new particle formation, Atmos. Chem. Phys., 10, 11223-11242, doi:10.5194/acp-10-11223-2010, 2010.

Philippin, S., Laj, P., Putaud, J.-P., Wiedensohler, A., de Leeuw, G., Fjaeraa, A., Platt, U., Baltensperger, U., and Fiebig, M.: EUSAAR An unprecedented network of aerosol observation in Europe, Earozoru Kenkyu, 24, 78-83, 2009.
Pierce, J. R. and Adams, P. J.: Efficiency of cloud condensation nuclei formation from ultrafine particles, Atmos. Chem. Phys., 7, 1367-1379, doi:10.5194/acp-7-1367-2007, 2007.

Pitchford, M. L., Schichtel, B. A., Gebhart, K. A., Barna, M. G., Malm, W. C., Tombach, I. H., and Knipping, E. M.: Reconciliation and interpretation of the Big Bend national park light extinction source apportionment: Results from the Big Bend regional aerosol and visibility observational study - Part 2., J. Air Waste Manage. Ass., 55, 1726-1732, 2005.

Platnick, S. and Twomey, S.: Determining the susceptibility of cloud albedo to changes in droplet concentration with the advanced very high resolution radiometer, J. Appl. Meteorol., 33, 334-347, 1994.

Reddington, C. L., Carslaw, K. S., Spracklen, D. V., Frontoso, M. G., Collins, L., Merikanto, J., Minikin, A., Hamburger, T., Coe, H., Kulmala, M., Aalto, P., Flentje, H., Plass-Dülmer, C., Birmili, W., Wiedensohler, A., Wehner, B., Tuch, T., Sonntag, A., O’Dowd, C. D., Jennings, S. G., Dupuy, R., Baltensperger, U., Weingartner, E., Hansson, H.-C., Tunved, P., Laj, P., Sellegri, K., Boulon, J., Putaud, J.-P., Gruening, C., Swietlicki, E., Roldin, P., Henzing, J. S., Moerman, M., Mihalopoulos, N., Kouvarakis, G., Ždímal, V., Zíková, N., Marinoni, A., Bonasoni, P., and Duchi, R.: Primary versus secondary contributions to particle number concentrations in the European boundary layer, Atmos. Chem. Phys., 11, 12007-12036, doi:10.5194/acp-11-12007-2011, 2011.

Rodríguez, S., Van Dingenen, R., Putaud, J.-P., Martins-Dos Santos, S., and Roselli, D.: Nucleation and growth of new particles in the rural atmosphere of Northern Italy - relationship to air quality monitoring, Atmos. Environ., 39, 6734-6746, 2005.

Schichtel, B. A., Gebhart, K. A., Malm, W. C., Barna, M. G., Pitchford, M. L., Knipping, E. M., and Tombach, I. H.: Reconciliation and interpretation of Big Bend national park particulate sulfur source apportionment: Results from the Big Bend regional aerosol and visibility observational study - Part I, J. Air Waste Manage. Ass., 55, 1709-1725, 2005.

Schurgers, G., Arneth, A., Holzinger, R., and Goldstein, A. H.: Process-based modelling of biogenic monoterpene emissions combining production and release from storage, Atmos. Chem. Phys., 9, 3409-3423, doi:10.5194/acp-9-3409-2009, 2009.

Seinfeld, J. and Pandis, S.: Atmospheric chemistry and physics: From air pollution to climate change, Wiley Interscience, 2nd edn., 2006.

Sihto, S.-L., Mikkilä, J., Vanhanen, J., Ehn, M., Liao, L., Lehtipalo, K., Aalto, P. P., Duplissy, J., Petäjä, T., Kerminen, V.-M., Boy, M., and Kulmala, M.: Seasonal variation of CCN concentrations and aerosol activation properties in boreal forest, Atmos. Chem. Phys., 11, 13269-13285, doi:10.5194/acp-11-13269-2011, 2011.

Spracklen, D. V., Carslaw, K. S., Kulmala, M., Kerminen, V.-M., Mann, G. W., and Sihto, S.-L.: The contribution of boundary layer nucleation events to total particle concentrations on regional and global scales, Atmos. Chem. Phys., 6, 5631-5648, doi:10.5194/acp-6-5631-2006, 2006.

Spracklen, D. V., Carslaw, K. S., Merikanto, J., Mann, G. W., Reddington, C. L., Pickering, S., Ogren, J. A., Andrews, E., Baltensperger, U., Weingartner, E., Boy, M., Kulmala, M., Laakso, L., Lihavainen, H., Kivekäs, N., Komppula, M., Mihalopoulos, N., Kouvarakis, G., Jennings, S. G., O’Dowd, C., Birmili, W., Wiedensohler, A., Weller, R., Gras, J., Laj, P., Sellegri, K., Bonn, B., Krejci, R., Laaksonen, A., Hamed, A., Minikin, A., Harri- 
son, R. M., Talbot, R., and Sun, J.: Explaining global surface aerosol number concentrations in terms of primary emissions and particle formation, Atmos. Chem. Phys., 10, 4775-4793, doi:10.5194/acp-10-4775-2010, 2010.

Tai, A. P. K., Mickley, L. J., Jacob, D. J., Leibensperger, E. M., Zhang, L., Fisher, J. A., and Pye, H. O. T.: Meteorological modes of variability for fine particulate matter (PM2.5) air quality in the United States: implications for PM2.5 sensitivity to climate change, Atmos. Chem. Phys., 12, 3131-3145, doi:10.5194/acp12-3131-2012, 2012.

Tunved, P., Hansson, H.-C., Kulmala, M., Aalto, P., Karlsson, H., Kristensson, A., Swietlicki, E., Dal Maso, M., Ström, J., and Komppula, M.: One year boundary layer aerosol size distribution data from five Nordic background stations, Atmos. Chem. Phys., 3, 2183-2205, doi:10.5194/acp-3-2183-2003, 2003.

Tunved, P., Hansson, H.-C., Kerminen, V.-M., Ström, J., M., D., Lihavainen, H., Viisanen, Y., Aalto, P., Komppula, M., and Kulmala, M.: High natural aerosol loading over boreal forests, Science, 312, 261-263, doi:10.1126/science.1123052, 2006.

van Dingenen, R., Raes, F., Putaud, J.-P., Baltensperger, U., Charron, A., Facchini, M.-C., Decesari, S., Fuzzi, S., Gehrig, R., Hansson, H.-C., Harrison, R. M., Hüglin, C., Jones, A., Laj, P., Lorbeer, G., Maenhaut, W., Palmgren, F., Querol, X., Rodriguez, S., Schneider, J., ten Brink, H., Tunved, P., Tørseth, K., Wehner, B., Weingartner, E., Wiedensohler, A., and Wåhlin, P.: A European aerosol phenomenology - I: physical characteristics of particulate matter at kerbside, urban, rural and background sites in Europe, Atmos. Environ., 38, 2561-2577, 2004.

Venzac, H., Sellegri, K., Villani, P., Picard, D., and Laj, P.: Seasonal variation of aerosol size distributions in the free troposphere and residual layer at the Puy de Dôme station, France, Atmos. Chem. Phys., 9, 1465-1478, doi:10.5194/acp-9-1465-2009, 2009.

von Storch, H. and Zwiers, F.: Statistical Analysis in climate Research, Cambridge Univ. Press., Cambridge, UK, 1999.

Wang, K. C., Dickinson, R. E., Su, L., and Trenberth, K. E.: Contrasting trends of mass and optical properties of aerosols over the Northern Hemisphere from 1992 to 2011, Atmos. Chem. Phys., 12, 9387-9398, doi:10.5194/acp-12-9387-2012, 2012.

Wang, X. L. and Swail, V.: Changes of extreme wave heights in Northern Hemisphere oceans and related atmospheric circulation regimes, J. Climate, 14, 2204-2221, 2001.
Weingartner, E., Nyecki, S., and Baltensberger, U.: Seasonal and diurnal variation of aerosol size distributions $(10<D<750 \mathrm{~nm})$ at a high-alpine site (Jungfraujoch $3580 \mathrm{~m}$ a.s.1.)., J. Geophys. Res., 104, 26809-26820, 1999.

WHO Working Group: Health Aspects of Air Pollution with Particulate Matter, Ozone and Nitrogen Dioxide, Tech. Rep. EUR/03/5042688, World Health Organization, Health Documentation Services, WHO Regional Office for Europe, Copenhagen, http://www.euro.who.int/document/e79097.pdf, 2003.

Wiedensohler, A., Birmili, W., Nowak, A., Sonntag, A., Weinhold, K., Merkel, M., Wehner, B., Tuch, T., Pfeifer, S., Fiebig, M., Fjäraa, A. M., Asmi, E., Sellegri, K., Depuy, R., Venzac, H., Villani, P., Laj, P., Aalto, P., Ogren, J. A., Swietlicki, E., Williams, P., Roldin, P., Quincey, P., Hüglin, C., Fierz-Schmidhauser, R., Gysel, M., Weingartner, E., Riccobono, F., Santos, S., Grüning, C., Faloon, K., Beddows, D., Harrison, R., Monahan, C., Jennings, S. G., O’Dowd, C. D., Marinoni, A., Horn, H.-G., Keck, L., Jiang, J., Scheckman, J., McMurry, P. H., Deng, Z., Zhao, C. S., Moerman, M., Henzing, B., de Leeuw, G., Löschau, G., and Bastian, S.: Mobility particle size spectrometers: harmonization of technical standards and data structure to facilitate high quality long-term observations of atmospheric particle number size distributions, Atmos. Meas. Tech., 5, 657-685, doi:10.5194/amt-5-657-2012, 2012.

$\mathrm{Xu}, \quad$ J. and Powell, A. M.: Uncertainty of the stratospheric/tropospheric temperature trends in 1979-2008: multiple satellite MSU, radiosonde, and reanalysis datasets, Atmos. Chem. Phys., 11, 10727-10732, doi:10.5194/acp-11-107272011, 2011.

Yoon, Y. J., Ceburnis, D., Cavalli, F., Jourdan, O., Putaud, J. P., Facchini, M. C., Decesari, S., Fuzzi, S., Sellegri, K., Jennings, S. G., and O'Dowd, C. D.: Seasonal characteristics of the physicochemical properties of North Atlantic marine atmospheric aerosols, J. Geophys. Res., 112, D04206, doi:10.1029/2005JD007044, 2007.

Yu, F., Luo, G., Turco, R. P., Ogren, J. A., and Yantosca, R. M.: Decreasing particle number concentrations in a warming atmosphere and implications, Atmos. Chem. Phys., 12, 2399-2408, doi:10.5194/acp-12-2399-2012, 2012.

Zhang, X. and Zwiers, F.: Comment on "Applicability of prewhitening to eliminate the influence of serial correlation on the MannKendall test" by Sheng Yue and Chun Yuan Wang, Water Resour. Res., 40, W03805, doi:10.1029/2003WR002073, 2004. 